\title{
RETIREMENT ISSUES ACROSS THE GLOBE
}

In the most advanced countries, the number of individuals aged 60 and older is increasing $60 \%$ faster than the population overall. This trend has a tremendous impact on the ratio of retirees to workers, which is estimated to reach one retiree per every four workers by 2050. As a result, the shrinking of the labor pool in proportion to the number of retirees will have a bigger impact on retirement than almost any other factor.

In recent years, almost every state has undergone a significant change in its pension system; increasing life expectancy and widely falling birth rates have increased - or are about to increase - the share of the population dependent on public pension schemes. At the same time, the growing importance given to austerity and balancing budgets has aggravated the situation and many states ran the risk of straining their pension systems.

Pension reforms undertaken to date are largely driven by the financial sustainability of the pension schemes and most of them will reduce the generosity of pension benefits to future generations. Some countries raised the contribution rate. Primarily, though, reforms concentrated on pension entitlement in order to compensate for longer life expectancy (and therefore for the longer expected pension entitlement period). As a result, many countries implemented parametric reforms to the way retirement income is calculated and to eligibility requirements.

Policy makers have also recently recognized the need to make saving accessible and incentives less complex. The states have sought for people to take greater 'self-responsibility' for their retirement income, but many people wish for some certainty with respect to the pensions they can expect. These goals might well be in conflict.

The issue of under-saving for retirement has been acknowledged and potential solutions have been debated for some time. What is relatively new is increasing awareness of the phenomenon of the 'ageing population' and the increasing urgency of the need to ensure sustainable solutions to the problem of how best to provide for the projected increase in the numbers of people in retirement. People's attitudes and behavior may be such that they save less for their retirement than is desirable or have what might be misplaced faith in alternative means of funding their retirement, such as housing wealth. 
Why save for retirement at all? The short answer is that because over a person's lifetime, income and wealth change as people move through their lifecycle. Saving allows one to accumulate wealth to draw on at times when income is lower, such as in retirement. Wealth is accumulated through the individual's working-life in order to fund consumption after retiring. Thus, rational individuals borrow when young, save in middle age, to build wealth, and spend these savings in old age.

\section{Saving for retirement}

Retirement was once a simple proposition: Individuals worked a lifetime and saved, employers provided a pension, and payroll taxes funded government benefits. The end result was a predictable income stream, generated from three stable sources that could provide a financially secure retirement. But demographics and economics have rendered old models unsustainable. In response to surging populations and expanding lifespans, employers continue to shift the responsibility of retirement funding to the individual, and policy makers are challenged to respond.

It's clear that in the coming decades, individuals will need to assume a greater share of retirement funding, but even as they do it's important to remember that ensuring retirement security is not solely their responsibility. Policy makers and employers still need to ensure workers have the tools, resources and education they need to be successful. People are assumed to retire above today's average retirement age and they are assumed to derive the maximum possible income from the assets they hold at retirement. The only way out of this box is for people to save more and/or work longer.

We should be interested in the subject of financing retirement for two reasons. First, we will almost certainly receive some retirement income from a social government policy designed to provide a minimum standard level of living. Second, we will probably need to save and invest a considerable part of our earnings to provide the overall standard of retirement living we would like.

\section{The saving cycle}

Without enough savings or ways to earn much money later in life, many of the oldest people could be left with modest Social Security checks as the only reliable, inflation-adjusted source of income. The responsibility for financial security in retirement is falling even more heavily on individuals than ever before and this trend is likely to continue as government resources in countries around the world become scarcer. It is becoming increasingly apparent that to ensure financial security in retirement, individuals need to take personal ownership of their destiny and view planning and saving for retirement as a serious, conscious and strategic pursuit. 
In the very earliest years of our career, we may spend most of our earnings, but thereafter we will spend less than we earn in order to support our desired standard of living in later years. After we leave our job or career, our wage or salary earnings will decrease or stop entirely. But we will want to have some sort of income in our later years. To provide this, we will need to spend less than our before-tax earnings during our working years. The social program in our country will likely do some of this for us by deducting required contributions from our wages or salary, likely obtaining additional amounts from our employer, then making payments to us after we retire. Our employer may deduct additional amounts and provide some post-retirement benefits as well. But in all likelihood we will want to further smooth the pattern of our spending over time by saving and investing some of our remaining discretionary income. To do this, we will need to move money from our working years to our retirement years. Increasingly, the burden will be on us to make intelligent saving and investment decisions.

\section{Ch. 1 - Fig. 1: Saving cycle}

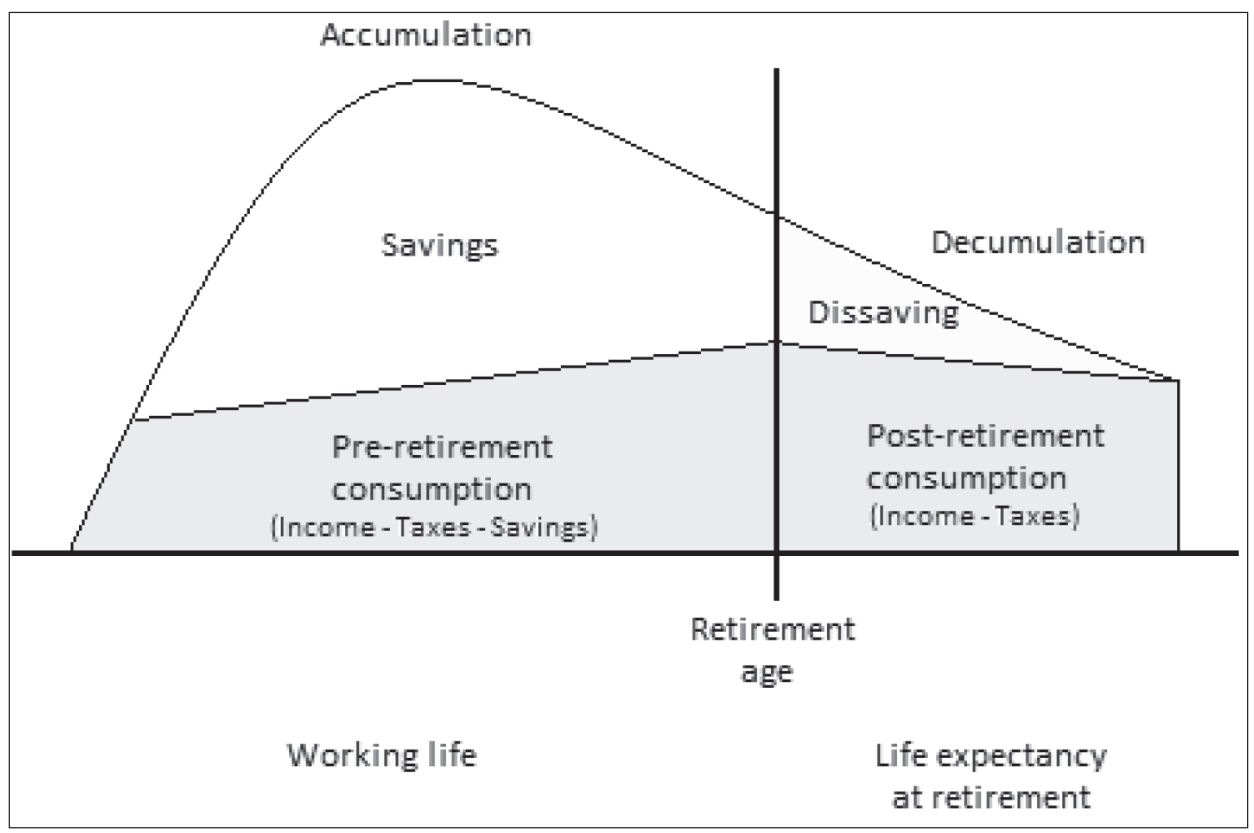

A simple strategy for individuals looking to ensure a secure retirement would be to save more and start saving sooner. In reality, it's not that simple. Life is complicated and brings with it many competing priorities. Saving for a child's education, caring for elderly parents, and other more immediate needs can often take precedence over the long-term objective of securing one's retirement funding.

Perhaps the best step forward for individuals is to set realistic goals. Beyond a stronger commitment to financial planning, we believe individuals who are now being asked to shoulder a larger share of retirement funding should look closely at the options available to them. If they have a pension, they should calculate their 
expected annual payout, along with potential government benefits they may receive, to determine just how much they will be required to contribute to their retirement income from their personal savings. Recognizing the pension gap early can be a powerful motivation to increase personal investments. As investors around the world look to ease the burden of funding retirement, financial advisors are stepping forward to help clients set clearer goals and establish more specific plans for both accumulating retirement assets and turning savings into a reliable income source in retirement. To clearly define retirement goals and expectations on retirement income is among the key trends that are shaping today's advisory practices. While they cannot resolve the deep structural challenges some governments face, financial advisors are in a position to drive demand for investing strategies that will empower individuals with greater control of their own financial security and deliver portfolios that can withstand market fluctuations over time.

If longer life is a financial threat, it is one that we can spot creeping toward us from decades away. The chances of extreme longevity are far smaller for current retirees and older workers than for their grandchildren. For younger workers, there's time to save more, to reimagine lives that include later life careers and to create better financial products to help ensure that income lasts a lifetime. And there's time for employers and governments to work together on creative solutions.

Fig. 2 is a likely pattern for the lifetime cycle of our income and spending. For each of several age categories, it plots the average annual before-tax wage or salary income for a consumer unit (household) in the United States in 2014, along with the average annual expenditure. While our experience will differ, it is likely to follow a similar cycle as we go through life.

\section{Ch. 1 - Fig. 2: U.S. consumer units, average income and expenditures}

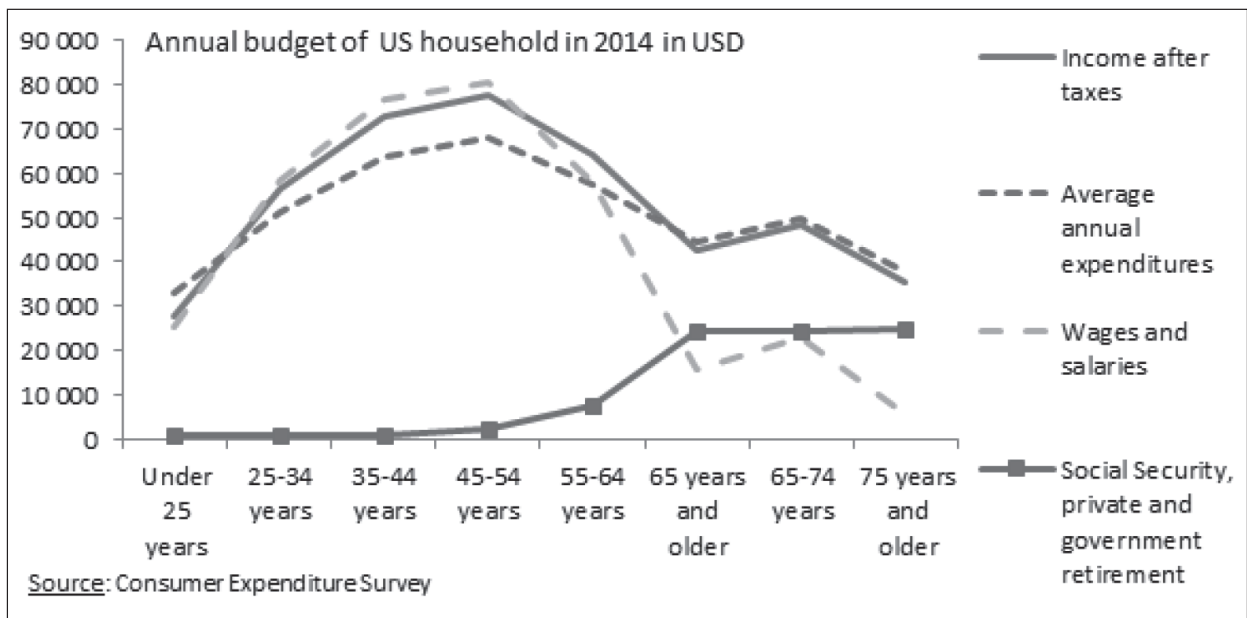

In the new world of retirement financing, we will very likely have to decide how much to save, how to invest the proceeds and what to do with the resulting 
money when we retire. Capital markets are highly competitive. It is very unlikely that we will find a strategy that provides long-term returns absolutely guaranteed to be greater than those available from low-risk government securities. Most other securities are risky in both the short-term and in the long-term. We may well want to invest at least part of your funds in some of them. But understand that, at best, our eventual retirement standard of living will be uncertain and could fall anywhere in a potentially wide range of possible outcomes.

The implication is that we should diversify widely across many risky investments so that the main risk we bear is that of a major fall in markets worldwide, due to fears of widespread recessions, financial crises and other catastrophes. Consider investing our retirement savings either directly or via an annuity in a combination of low-risk inflation-protected securities and one or more funds representing a global portfolio of bonds and stocks. The more willing we are to take on added risk in the pursuit of added long-run return, the greater the proportion we should invest in the risky portfolio. However, the primary personal asset of most citizens is their own homes. The other assets of most families are modest, and what one household saves scarcely offsets what another house-hold borrows. As a result, the aggregate savings rate, except for employer-sponsored pensions, is sometimes not enough.

Many reasons have been advanced to explain the anemic savings rate in the United States, especially as it has fallen over the past 10 years. Until recently, one reason was the decline in the percentage of people in the population between the ages of 45 and 64 , the age group considered the most aggressive savers. It was thought that once baby boomers entered this age group, the personal savings rate would climb. However, recent statistics indicate that, although many baby boomers have already entered the traditionally peak savings years, personal savings rates continue to fall.

Ch. 1 - Fig. 3: U.S. saving rate

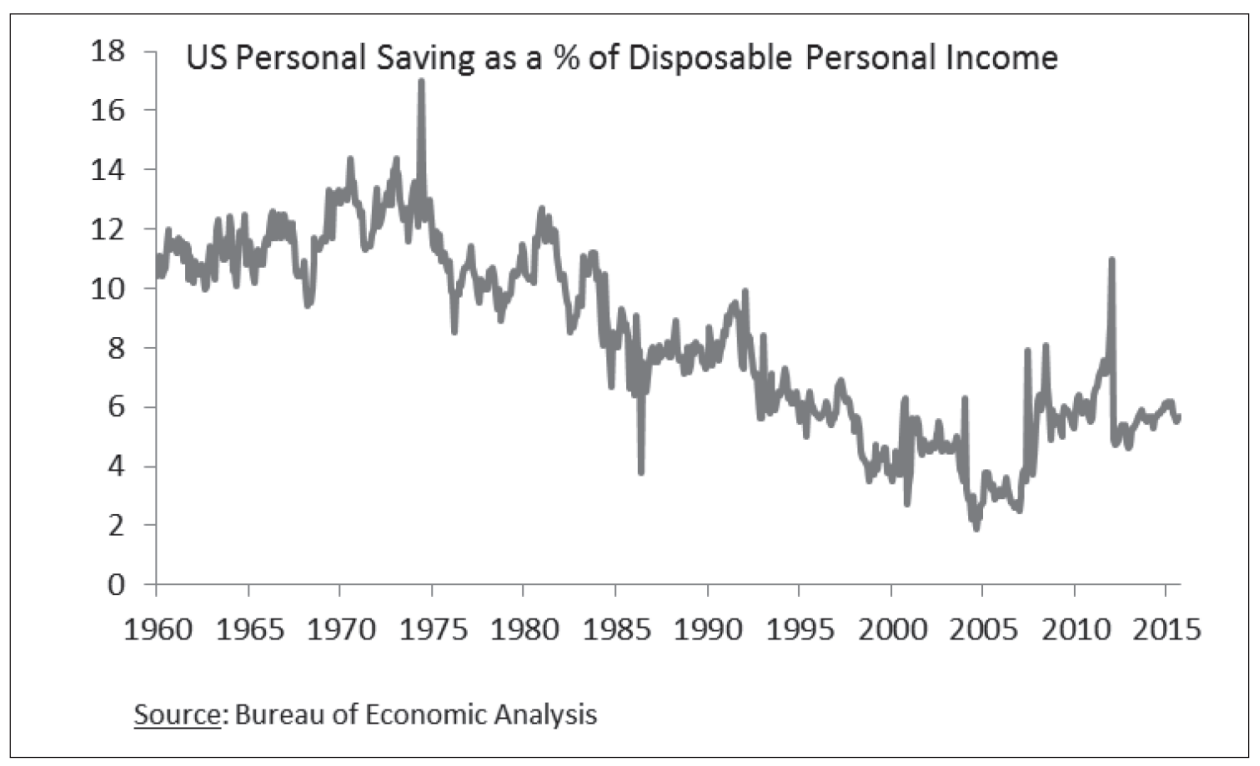


Government, Employers and Individuals, the three legs of the global retirement savings stool, each have a role to play in improving the state of savings around the world. Governments need to work together to institute meaningful, difference-making reforms. Employers need to be more flexible and open to considering programs that can broaden coverage. And individuals need to realize that they can no longer depend on the other two legs of the stool, and instead should focus on the factors they themselves can control, such as establishing a plan, setting goals and being more engaged. Usually people achieve precautionary saving(s) (non-expenditure of a portion of income) that occurs in response to uncertainty regarding future income. The precautionary motive to delay consumption and save in the current period rises due to the lack of completeness of insurance markets. Accordingly, individuals will not be able to insure against some bad state of the economy in the future. They anticipate that if this bad state is realized, they will earn lower income. To avoid adverse effects of future income fluctuations and retain a smooth path of consumption, they set aside a precautionary reserve, called precautionary savings, by consuming less in the current period, and resort to it in case the bad state is realized in the future. The US Bureau of Labor Statistics shows that expenditures tend to decrease after age 75. But in light of expected future health care costs, it is prudent to assume that reduction in spending for expenditure categories such as leisure and entertainment will be replaced by increased medical expenses.

\section{Ch. 1 - Fig. 4: U.S. 65- 74 expenditures and inflation}

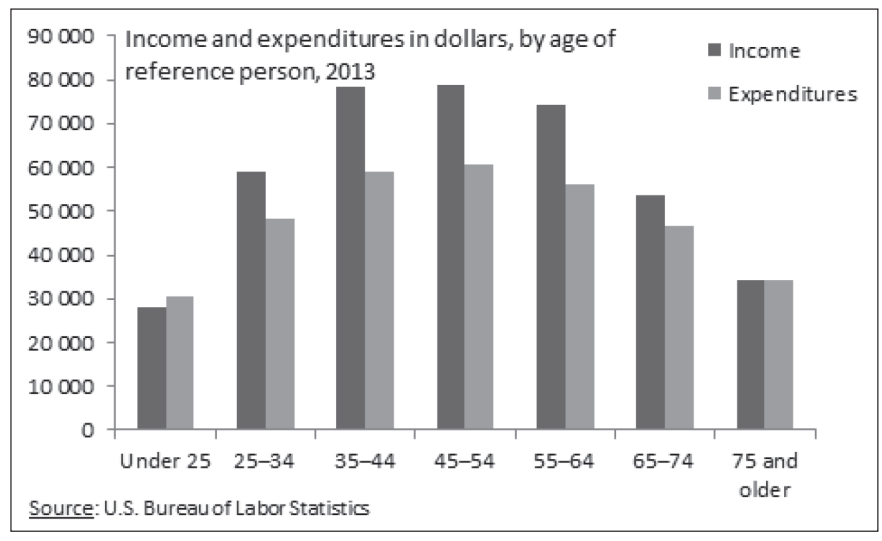

According to data from the BLS, the average annual expenditures of someone in the 65 to 74 age group in the US increase faster than CPI Inflation. This implies that retirees will need significant assets at the point of retirement, and will need to efficiently utilize those assets to generate enough income to fill the income-expenditure gap. 


\section{Ch. 1 - Fig. 5: U.S. 65- 74 expenditures and inflation}

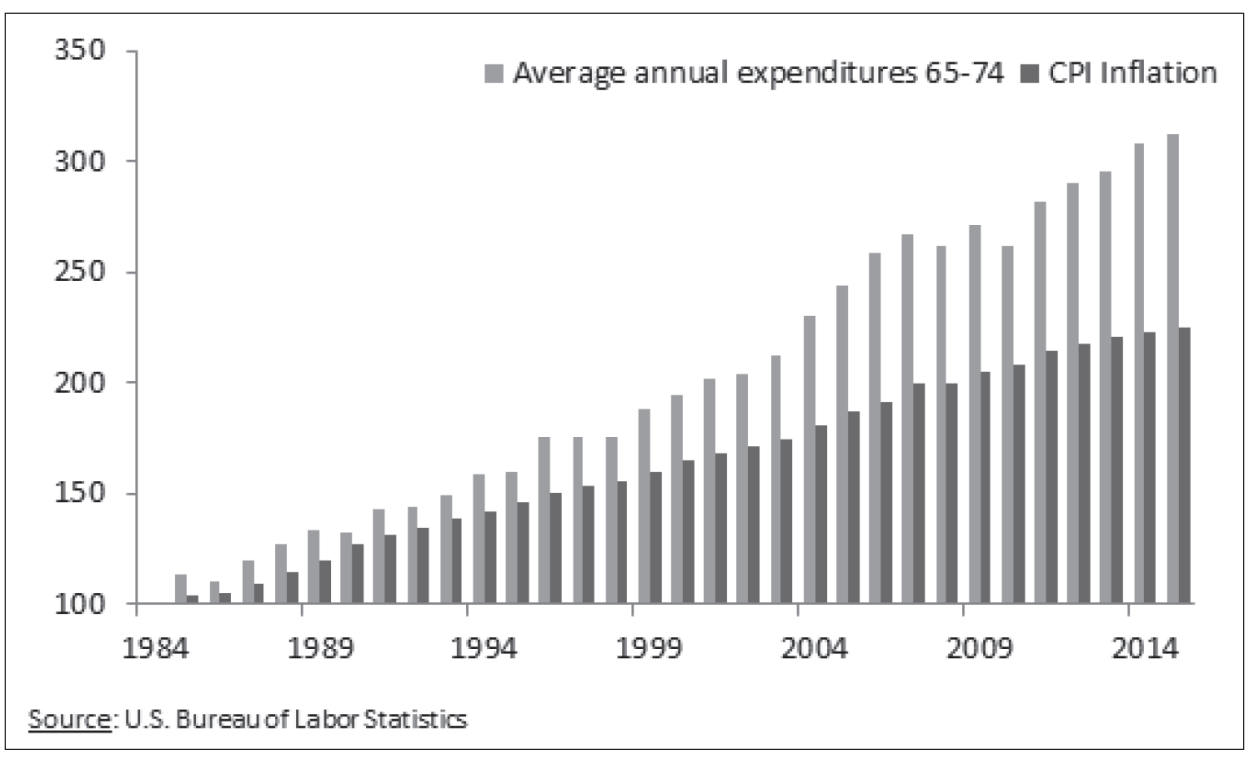

\section{The replacement rate, a key notion}

Virtually all developed countries have social retirement programs. Contributions from employees and employers are mandatory and benefits are paid after a specified age as long as the beneficiary is alive. Once payments begin, the annual amounts are generally increased by the amount of inflation, as measured by a government index of the cost of living. While these provisions may not fully reflect changes in the cost and quality of the goods and services we personally will consume, the goal is to allow us to maintain a relatively constant standard of living in retirement.

One of the common measures that specifies the ultimate outcome of longterm retirement saving is the replacement rate. This is the standard measure of the generosity of a social retirement plan. Income replacement rates are as important as a part of adequacy as poverty prevention. Technically speaking, the replacement rate $^{6}$ is defined as the ratio of the pension to the average wage during the lifetime or a specified period of lifetime. In a more qualitative assessment, it determines the degree to which the pension enables the pensioners to maintain living standards during retirement. One of the common measures that specifies the ultimate outcome of long-term retirement saving is the replacement rate. It is the ratio showing the income of a retiree in comparison to his or her income received during working years.

6. The net pension replacement rate is an individual's net pension entitlement divided by net pre-retirement earnings. This rate shows how effectively each country's pension system provides a retirement income. In comparison to the gross replacement rate, taxes on both pensions and pre-retirement earnings have been accounted for already. Replacement rates can be further disaggregated according to income levels. 
Figure 6 shows the ratios of pre-retirement income that were replaced by retirement benefits from the social system at retirement in France across time.

\section{Ch. 1 - Fig. 6: Replacement rate across time in France}

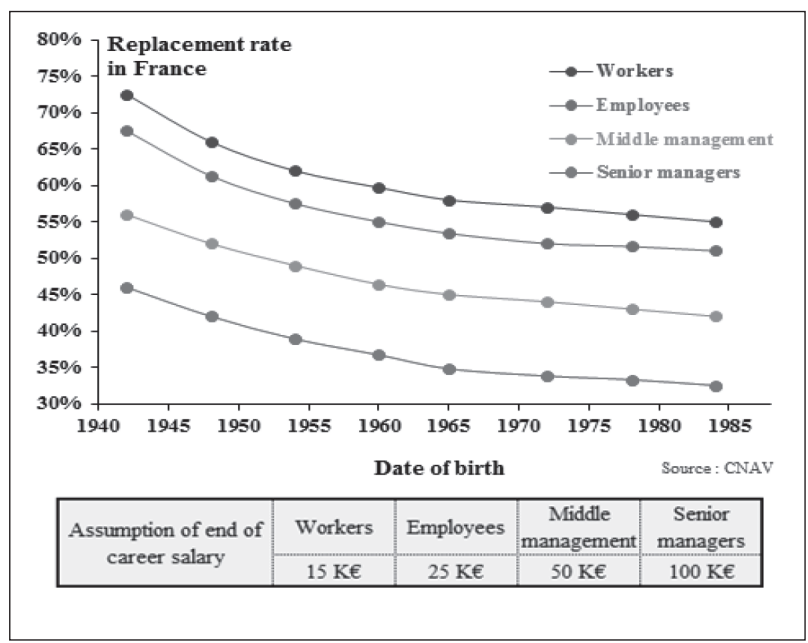

This ratio shows generally the income of a retiree in comparison to his or her income received during working years. This comparison can be done either on an individual basis (i.e. pension benefit of a retiree compared to his or her salary, the career average or final one) or a plan basis (not allowing for specific individual risks, such as labor market risks). It may also be calculated on a national basis (i.e. the average pension benefit received by every retiree in relation to the average salary in the economy). Naturally, there can be variations. For example, this ratio can be calculated for a particular cohort where their pension income is related to the average salary in the economy prevailing at the moment of their retirement or the moment of calculation.

The lack of significant true savings and investment makes social retirement programs vulnerable to serious problems of underfunding. The frequent use of questionable assumptions about the growth of the economy, unemployment, inflation and other macro- economic variables can lead to situations that generate pressure to reduce the generosity of such plans, adversely affecting beneficiaries.

One striking feature is the fact that a person relying solely on a social program for post-retirement income would typically suffer an income decrease of more than $50 \%$. The other is that the replacement rates in a given country are considerably lower for those with higher incomes (Figure 8). This is intentional. Such programs are designed to redistribute income from higher-income people to those less fortunate. Social programs are typically not intended to fully provide a relatively constant 


\section{Ch. 1 - Fig. 7: Gross and net replacement rates across countries}

\begin{tabular}{|c|c|c|c|c|c|c|c|c|}
\hline \multirow[b]{2}{*}{$\begin{array}{c}\text { Source: Based on } \\
\text { Dice Database (2015) } \\
\text { (Empty cells: Data } \\
\text { not available) }\end{array}$} & \multicolumn{4}{|c|}{$\begin{array}{l}\text { Gross pensions replacement rates } \\
\text { (percentage of individual earnings), } 2013\end{array}$} & \multicolumn{4}{|c|}{$\begin{array}{l}\text { Net pensions replacement rates } \\
\text { (percentage of individual earnings), } 2013\end{array}$} \\
\hline & Public & $\begin{array}{l}\text { Mandatory } \\
\text { private }\end{array}$ & $\begin{array}{l}\text { Voluntary } \\
\text { DC }\end{array}$ & $\begin{array}{l}\text { Total with } \\
\text { voluntary }\end{array}$ & Public & $\begin{array}{l}\text { Mandatory } \\
\text { private }\end{array}$ & $\begin{array}{l}\text { Voluntary } \\
\text { DC }\end{array}$ & $\begin{array}{l}\text { Total with } \\
\text { voluntary }\end{array}$ \\
\hline Australia & 13.6 & 38.7 & & 52.3 & 17.5 & 50.1 & & 67.7 \\
\hline Belgium & 41.0 & & 15.1 & 56.2 & 50.1 & & 18.5 & 68.6 \\
\hline Brazil & 57.5 & & & 57.5 & 63.5 & & & 63.5 \\
\hline Canada & 39.2 & & 33.9 & 73.1 & 50.6 & & 43.8 & 94.4 \\
\hline China & 77.9 & & & 77.9 & 84.7 & & & 84.7 \\
\hline Denmark & 30.6 & 47.9 & & 78.5 & 30.1 & 47.3 & & 77.4 \\
\hline France & 58.8 & & & 58.8 & 71.4 & & & 71.4 \\
\hline Germany & 42.0 & & 16.0 & 58.0 & 55.3 & & 21.1 & 76.4 \\
\hline India & 55.8 & & & 55.8 & 64.1 & & & 64.1 \\
\hline Italy & 71.2 & & & 71.2 & 78.2 & & & 78.2 \\
\hline Japan & 35.6 & & & 35.6 & 40.8 & & & 40.8 \\
\hline Netherlands & 29.5 & 61.1 & & 90.7 & 33.0 & 68.2 & & 101.1 \\
\hline Russian Federation & 30.6 & 17.3 & & 47.9 & 35.2 & 19.9 & & 55.1 \\
\hline Spain & 73.9 & & & 73.9 & 80.1 & & & 80.1 \\
\hline Sweden & 33.9 & 21.7 & & 55.6 & 33.7 & 21.5 & & 55.3 \\
\hline Switzerland & 32.0 & 23.1 & & 55.2 & 43.4 & 31.3 & & 74.7 \\
\hline United Kingdom & 32.6 & & 34.5 & 67.1 & 38.0 & & 40.2 & 78.1 \\
\hline United States & 38.3 & & 37.8 & 76.2 & 44.8 & & 44.2 & 88.9 \\
\hline
\end{tabular}

lifetime standard of living for everyone. Rather, the goal is to provide a "safety net" with all but those with the lowest incomes expected to obtain additional sources of retirement income. To improve the sustainability of the system we can mention boosting the low level of retirement saving, increasing the old age dependency ratio and working on the substantial government debt, which is threatening the state's ability to deliver adequate retirement incomes. The lack of savings culture and current minimum auto-enrolment contributions are unlikely to deliver adequate retirement outcomes.

\section{Ch. 1 - Fig. 8: Net replacement rates for various level of income}

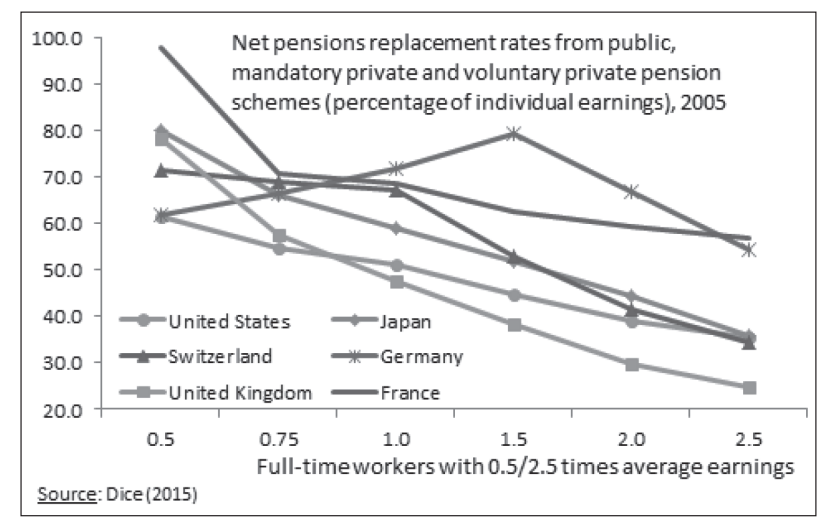

If we are like most people, we would like to retire early and enjoy the same lifestyle during retirement that we had while working. To keep our same lifestyle in retirement, we will need to "replace" $70 \%$ to $90 \%$ of our annual income with income 
from other sources after we retire. One way to measure the amount of retirement income necessary to fulfill these expectations is through the calculation of replacement ratios. These ratios indicate the percentage of preretirement income that will be needed to maintain the same standard of living after retirement. In general, most retired people will not have to replace their entire income to maintain their standard of living. Most will pay lower taxes because they will have no, or lower, earnings subject to payroll taxes, and certain work-related expenses will disappear.

The National Retirement Risk Index (NRRI) measures the share of working-age American households "at risk" of being unable to maintain their pre-retirement standard of living in retirement. The Index ${ }^{7}$ is calculated by comparing households' projected replacement rates - retirement income as a percent of pre-retirement income - with target replacement rates that would allow them to maintain their standard of living. To determine the share of the population that will be at risk requires comparing projected replacement rates with the appropriate target rates. Target replacement rates are estimated for different types of households assuming that households spread their income so as to have the same level of consumption in retirement as they had before they retired. Households whose projected replacement rates fall more than 10 percent below the target are deemed to be at risk of having insufficient income to maintain their pre-retirement standard of living. The Index is simply the percentage of all households that fall more than 10 percent short of their target.

Ch. 1 - Fig. 9: National Retirement Risk Index

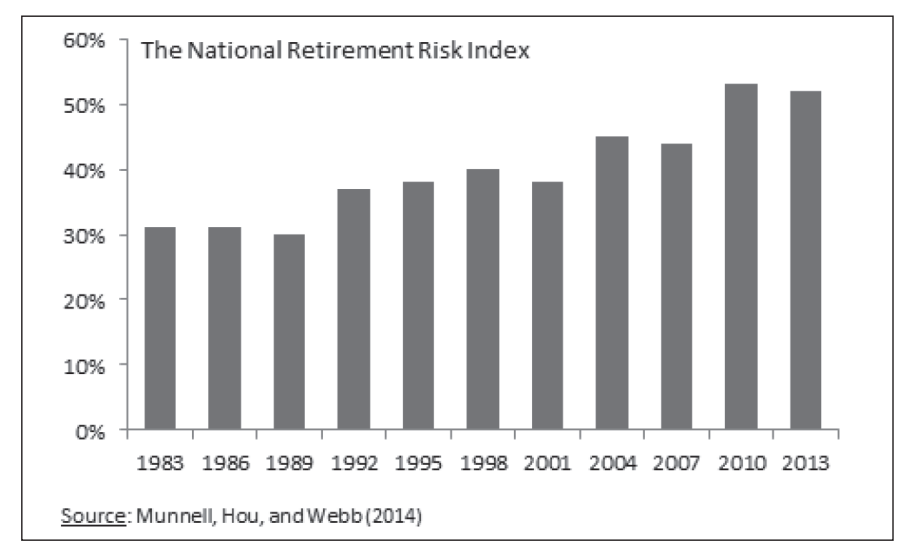

7. Munnell, A. H., Webb, A. \& Cannon Fraenkel, R. 2013. “The Impact of Interest Rates on the National Retirement Risk Index." Issue in Brief 13-9. Chestnut Hill, MA: Center for Retirement Research at Boston College. 


\section{Global demographics trends}

The world's working-age population is shrinking faster than expected, leaving fewer people to support a growing number of seniors. Conventional measures of old-age dependency calculate the ratio of people ages 65 and older with those of working age 15 to 64. As seniors increasingly outnumber people still in the workforce, pressures rise on investment pools, medical systems and funds to build economies for future generations.

Aging populations pose a threat to the economics behind social welfare and retirement systems globally. Europe, where state-funded pensions are the backbone of retirement security, may feel the greatest pressure over the next half century. The number of individuals above the age of 65 in EU member countries is expected to increase from less than 20\% to close to one-third of the population by 2060. The effects of this shift will be greatest in those member countries where annual tax revenues fund retirement benefits. Where the EU currently has close to four working people for every person of retirement age, the old age dependency ratio is expected to double by 2060, leaving just two working age people for every one retiree.

With fewer workers supporting a greater number of retirees, policy makers who rely on current retirement models would be left with just three options: reduce retirement benefits, increase taxes and/or increase statutory retirement age. These may all play a role, but in reality, a greater share of the responsibility will shift to employers, who will need to ensure workplace benefits are available, and individuals, who will need to take full advantage of those benefits to ensure a more secure retirement.

Of course, the financial burdens placed on young people around the world as a result of aging populations is highly dependent upon the extent of social services that have been promised and just how poorly funded those Ponzi schemes are. Advanced economies face rather different challenges depending on the social provisions they have promised and the declines in fertility that have occurred in these nations.

Longevity risk for the individual can be defined as the extent to which an individual's life span significantly exceeds his or her life expectancy. The financial cost of longevity risk is that either individual will outlive their retirement savings or alternatively, they will underspend their savings, leading to a lower income over retirement and an unintentional bequest on death.

During the past 50 years, the world's population has increased dramatically. This trend is projected to continue; the world population is expected to reach 9.1 billion by $2050^{8}$. Most future growth will occur in less developed countries, where the population is increasing more than five times as fast as that in developed countries.

8. United Nations, Population Division, Department of Economic and Social Affairs, World Population Prospects: The 2015 Revision. 


\section{Ch. 1 - Fig. 10: Total population}

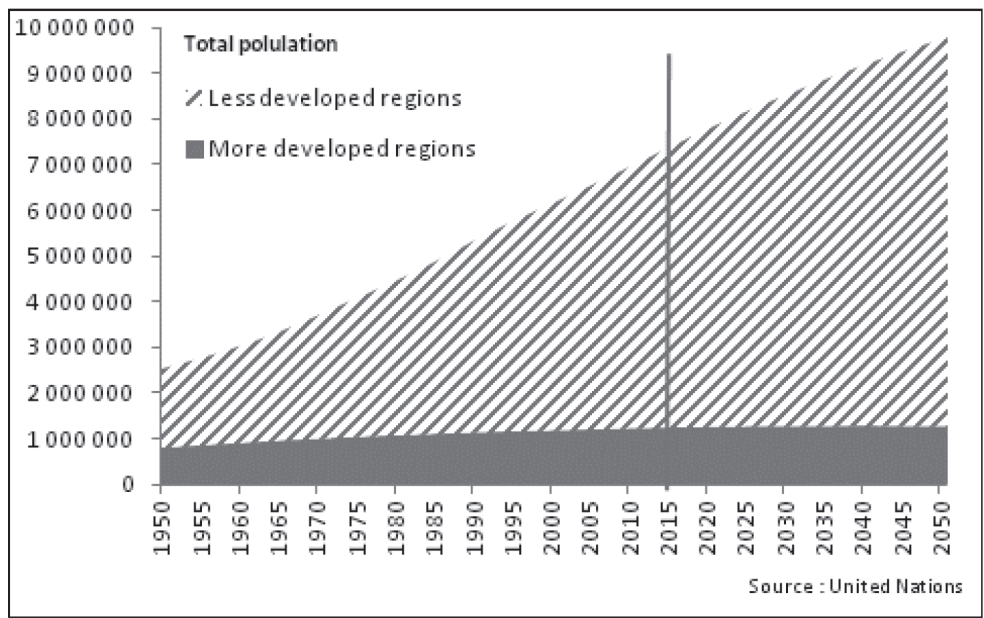

Although at a slower rate than the recent years, the world population continues to grow. Today, it is growing by 1.18 percent per year, or approximately an additional 83 million people annually. The world population is projected to increase by more than one billion people within the next 15 years, reaching 8.5 billion in 2030, and to increase further to 9.7 billion in 2050 and 11.2 billion by 2100 .

The phenomenal growth in world population has occurred despite a marked decline in the growth rate of the world's population, which fell to $1.2 \%$ a year in 2000-05, and is expected to drop further to $0.38 \%$ a year by 2045-50, because of the large number of women of childbearing age, a phenomenon known as "population momentum". Even so, the growth rate of the world's population has been on a downward trend and, in developed countries, will turn negative by 2030. Naturally, numbers like this suggest that population aging will put pressure on government health spending.

Ch. 1 - Fig. 11: Annual growth rate of population

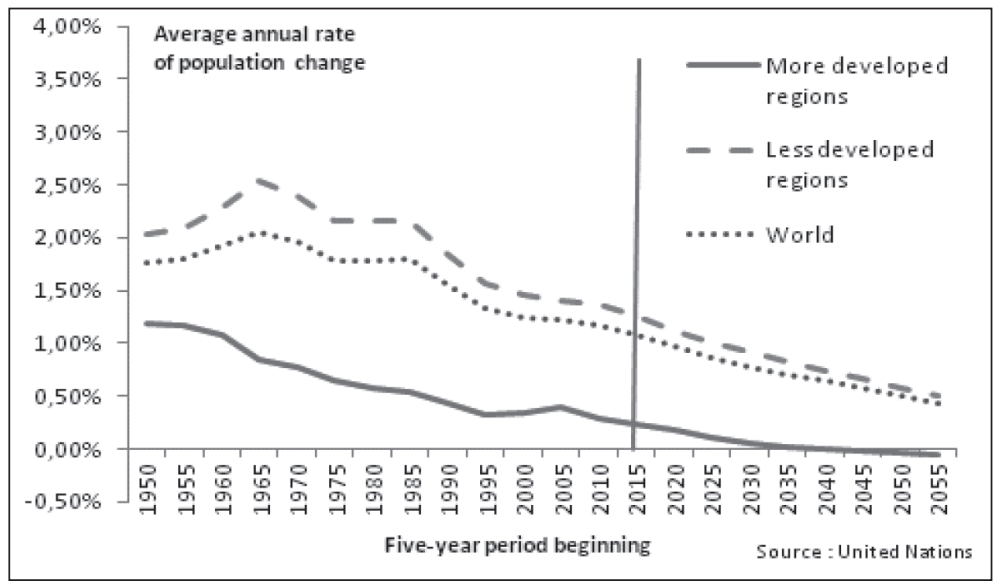


Birth rates have fallen and are expected to drop further in less developed countries, whereas in more developed countries, they are expected to remain fairly constant. At the same time, death rates are holding fairly steady. Slower growth of the world's population is largely due to the decline in birth rates, particularly in less developed countries over the past 50 years.

\section{Ch. 1 - Fig. 12: Birth and death rates}

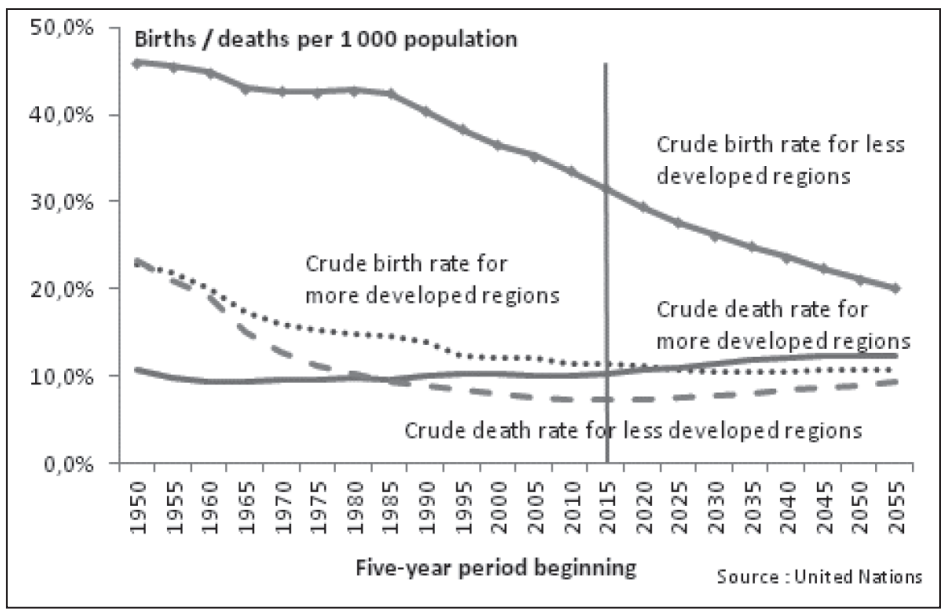

Declining birth rates, combined with increases in life expectancy, are leading to population aging. The number of people in less developed countries aged 60 or over is expected to exceed the number of 12- to 24-year-olds by 2045, a phenomenon that occurred in more developed countries in the late 1990s. In developed countries, the size of the ederly population is about to surpass that of the 12-24 age groups. Over the next 50 years, the proportion of the population aged 65 and over is expected to double.

\section{Ch. 1 - Fig. 13: Total population for different ages}

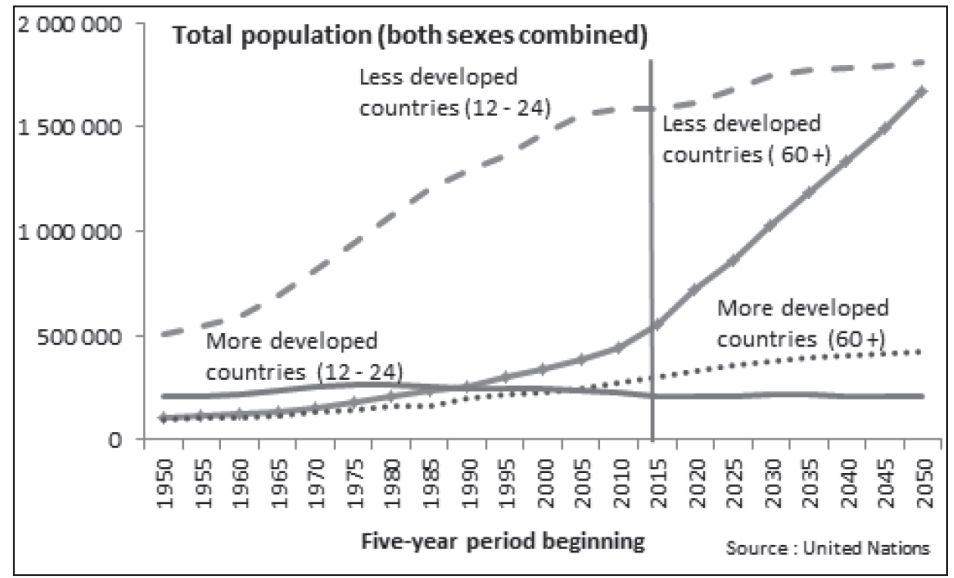


Clearly, increased life expectancy adds to the costs of any given social retirement plan. But there is another factor that has greatly affected the financial status of such plans around the globe. We are having fewer children. Demographers focus on a statistic termed the fertility rate, roughly, the number of children per woman who lives through her reproductive life.

\section{Ch. 1 - Fig. 14: Fertility rate}

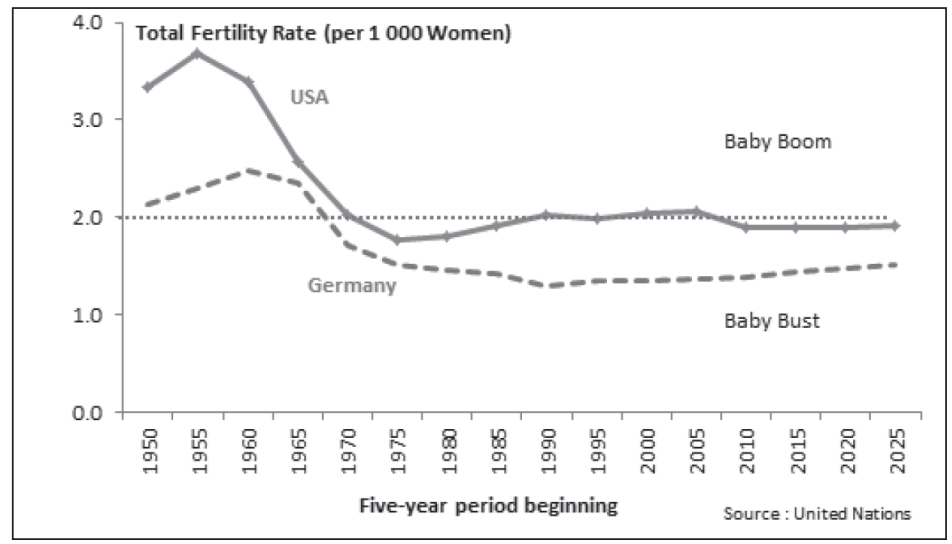

For many countries, the effects of actual and predicted increases in life expectancy, plus decreases in fertility rates, can be observed through the decline of the old age support rates, which relates the number of those who are capable of providing economic support to the number of older people that may be materially dependent on the support of others. The support rate indicator is the population aged 20 to 64 as a ratio of those aged 65 and over. The old age support rate is the ratio of the population who may be economically active to older people who are more likely to be economically inactive. It thus provides an old age related indicator of the number of active people potentially economically supporting inactive people. It also gives a broad indication of the age structure of the population. With the world's working-age population shrinking faster than expected, fewer people are left to support a growing number of seniors.

In Figure 15, each line shows the value of an actual or projected old age support ratio, computed by dividing the number of people from age 20 to 64 by the number of those 65 and over. The former are thought to be of "working age" and the latter of "pension age", although such an interpretation may be too simple, especially in the future. In any event, the ratio is projected to decrease dramatically in every country shown. Note that all the people that will then make up the older age group are alive today, as are many of those that will be in the younger group.

Changes in the old age support rate depend on past and present mortality, fertility rates and, to a much lesser degree, on net migration. Countries which have the highest old age support rates currently experience the biggest falls, indicating support rates becoming more similar between countries during the next 40 years. 


\section{Ch. 1 - Fig. 15: Old support age ratio}

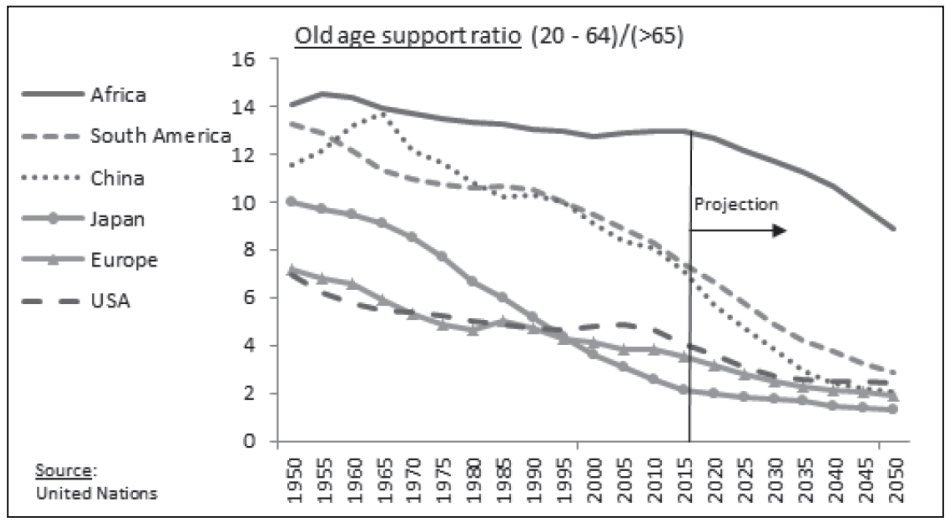

The chart graphically illustrates future convergence of support. The main reason for convergence rates between countries in support rates is the lagged effect of convergence in fertility rates across the OECD. The projections of support rates are highly conditional on projections of likely fertility rates over the next forty years. Whether such support rates cause policy problems depends in part on the health and labour market attachments of those over age 65, which will influence their ability to support themselves.

\section{Ch. 1 - Fig. 16: Total dependency ratio}

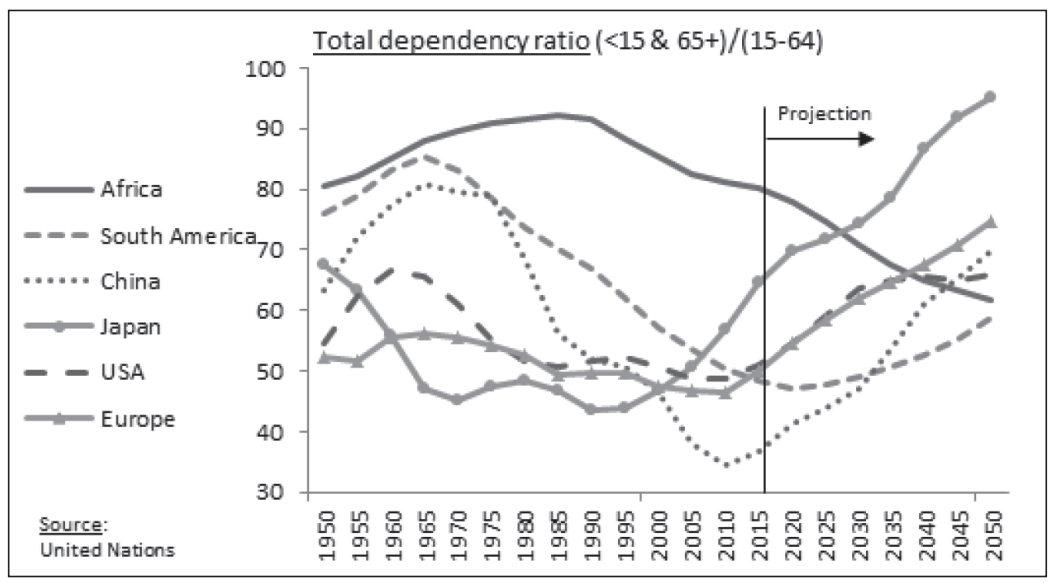

Increases in the median age, the age at which 50 percent of the population is older and 50 percent is younger, are another way of looking at population aging. The current 13-year difference in median age between developed and developing countries is much larger than it was 60 years ago. As countries develop, people tend to move from rural to urban areas. The world's urban population is expected to grow by 1.8 percent a year between 2000 and 2030, almost twice as fast as global population growth. 
Industrial countries have largely completed what is called the "demographic transition" - the transition from a largely rural agrarian society with high fertility and mortality rates to a predominantly urban industrial society with low fertility and mortality rates. At an early stage of this transition, fertility rates fall, leading to fewer young mouths to feed. During this period, the labor force temporarily grows more rapidly than the population dependent on it, freeing up resources for investment in economic development and family welfare. Other things being equal, per capita income grows more rapidly too. That's the first dividend. This dividend period is quite long, lasting five decades or more, but eventually lower fertility reduces the growth rate of the labor force, while continuing improvements in old-age mortality speed growth of the elderly population. Now, other things being equal, per capita income grows more slowly and the first dividend turns negative.

But a second dividend is also possible. A population concentrated at older working ages and facing an extended period of retirement has a powerful incentive to accumulate assets - unless it is confident that its needs will be provided for by families or governments. Whether these additional assets are invested domestically or abroad, national income rises. In short, the first dividend yields a transitory bonus, and the second transforms that bonus into greater assets and sustainable development. These outcomes are not automatic but depend on the implementation of effective policies. Thus, the dividend period is a window of opportunity rather than a guarantee of improved standards of living.

\section{Ch. 1 - Fig. 17: Illustration of demographic transition}

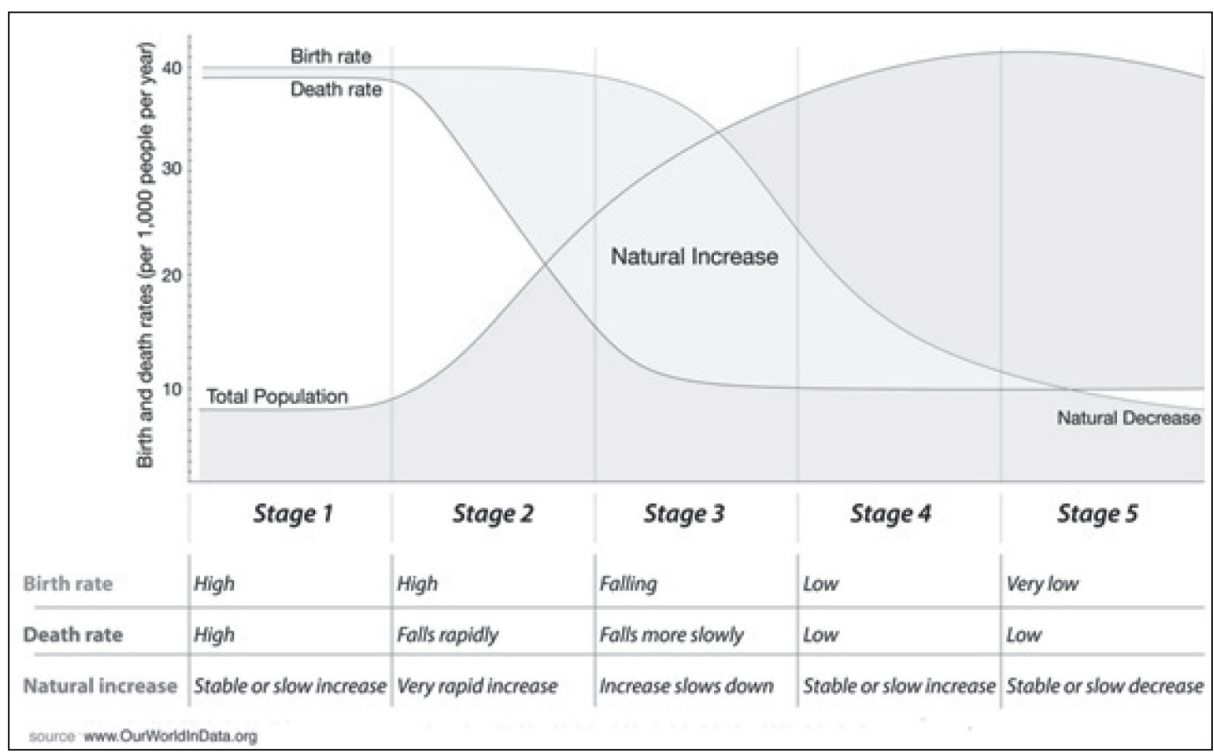

Developing countries are still working their way through the demographic transition (as illustrated by China's age pyramids). During the early stage, the number of children rises rapidly as mortality falls. Later, at an intermediate stage, fertility begins 
to decline, reducing the number of children, and the share of the working-age population increases. During the late stage, low mortality and fertility increase the share of the older population, a process known as population aging. Countries at the intermediate stage have the opportunity to exploit the first demographic dividend. The second dividend begins toward the end of the intermediate phase and extends through the late phase, but the policies for realizing the second dividend are best established during the intermediate phase. The size of the dividends depends on how much people produce and consume at each age. Multiplying the population age distribution by these age profiles of production or consumption, we find the effective numbers of producers and consumers; the ratio of producers to consumers is the "support ratio." During the dividend phase, the support ratio rises. A 1 percent increase in this support ratio allows consumption at each age to rise by 1 percent with no increase in the share of GDP consumed.

\section{Ch. 1 - Fig. 18: Japan, USA and China's age pyramids in 1960, 2000 and 2040}

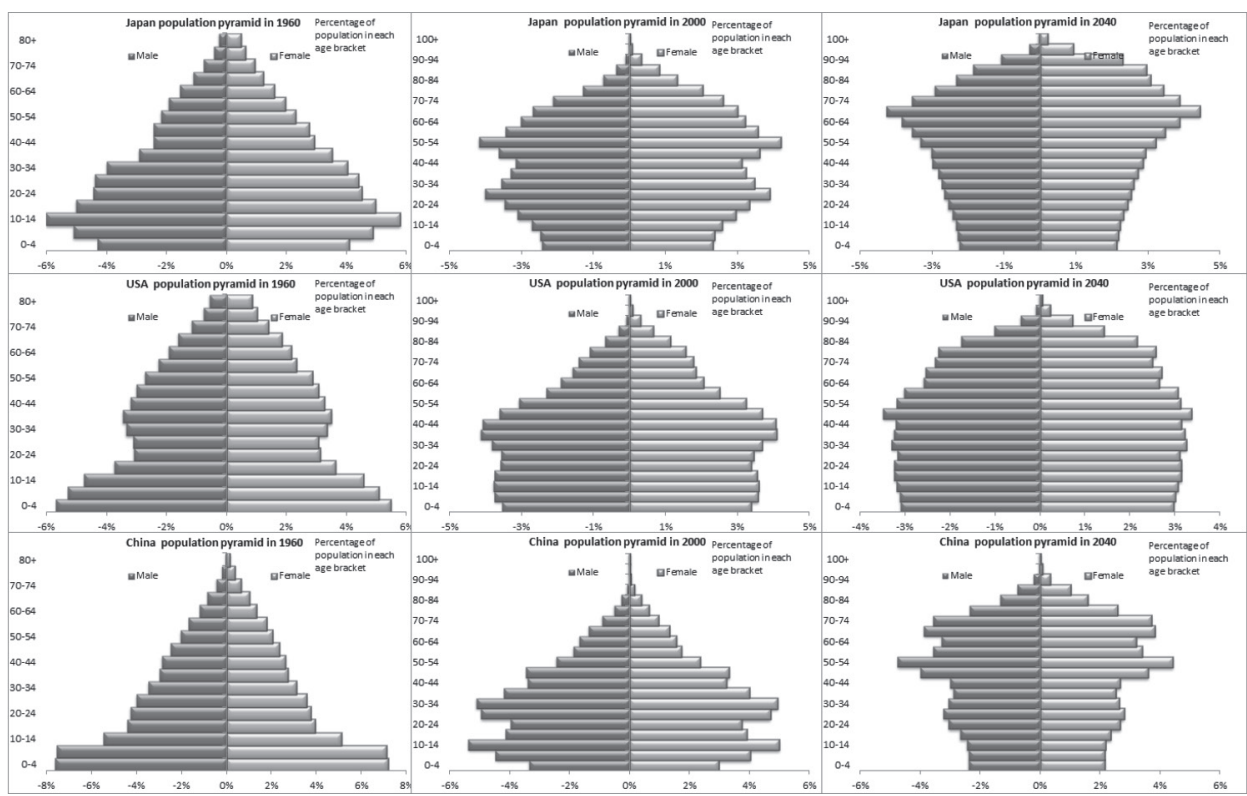

How much of the first dividend is realized during this demographic window of opportunity hinges on key features of the economic life cycle. The productivity of young adults depends on schooling decisions, employment practices, the timing and level of childbearing, and policies that make it easier for young parents to work. Productivity at older ages depends on health and disability, tax incentives and disincentives, and, particularly, the structure of pension programs and retirement policies. How much of the second dividend is realized depends on how a society supports its elderly. In the developing world, the elderly are supported by their families and the public sector, but, in addition, they depend on assets they have accumulated during their working years (housing, funded pensions, and personal 
savings, among other things). As populations age, the support burden placed on families and governments will increase relative to GDP, a matter of great concern in many countries. But through the second dividend, increased numbers of middle-aged workers may substantially raise capital relative to GDP if policies encourage workers to save for their retirement.

To the extent that countries meet the challenge of aging by expanding unfunded familial or public transfer programs, asset growth will be reduced, and the second dividend will be diminished. By contrast, if workers are encouraged to save and accumulate pension funds, population aging can boost capital per worker, productivity growth, and per capita income. Thus, policymakers, especially in developing countries, will need to focus on establishing financial systems that are sound, trusted, and accessible to the millions who wish to secure their financial futures. The time to do so is now so that, as a population ages, its growth-inducing potential will be realized.

\section{The typology of pensions-systems}

Detailed comparison of pension systems across countries is a difficult task. All the industrialized countries have set up schemes whereby workers are assured of a certain level of income upon their retirement. These schemes are in the first instance part of a public statutory social security system (mostly financed through taxes or social contributions, therefore classified as Pay-As-You-Go ${ }^{9}$ systems) and, in the second instance, part of mandatory or voluntary contribution schemes by the employer/employee or an individual. The presence and the degree of development of both systems vary widely across countries, however, and it is even not always possible to trace a line between social security, employment-related systems and voluntary contributions.

There have been numerous typologies of retirement income systems. Hereafter, we will use a descriptive classification that may be applied consistently to several countries with diverse retirement income systems. Pension systems have traditionally been characterized based on the original reasons for their introduction. Two systems can broadly speaking be distinguished in this historical respect: the Beveridgean and the Bismarckian systems.

- Under the Beveridgean system, social security benefits ensure for each citizen or resident a basic income, a flat-rate pension (potentially means-tested) independent of his or her profession and earnings during active employment. Citizens are free to supplement this income with occupational provisions as part of a contract with an employer or through collective bargaining ${ }^{10}$. It largely corresponds today to a system of a flat rate or social allowance for PAYG

\section{PAYG}

10. This system was put in place in Denmark, Ireland, the Netherlands, and the United Kingdom in various forms. 
systems complemented by an important, often mandatory or semi-mandatory, occupational scheme and a voluntary savings part.

- The Bismarckian system assumes that people have a right to social security benefits only insofar as they acquire that right by work. The pension benefits are earnings-related and profession-related, generally subject to maximum limits. The Bismarckian system is often supplemented with a minimum pension guarantee for people who have had only weak attachment to the labor force. This system, generally speaking, corresponds today ${ }^{11}$ to a more differentiated formula for the basic PAYG scheme with a correspondingly lower role for funded occupational schemes.

However, even this Bismarckian/Beveridgean distinction is to some extent arbitrary, as both systems have evolved differently within national contexts and have gone through reforms. One example of this is that funded occupational pension schemes often exist within the Bismarckian system and have expanded recently.

The main division of pension schemes has been made on the basis of a three-pillar system ${ }^{12}$. This has developed into - and been broadly interpreted as - a public pillar (prevention of poverty in old age), an occupational pillar (adequate replacement rates) and a voluntary individual pillar (individual choice to save additionally for pension purposes).

- 1 st Pillar: Avoiding poverty in old age. This covers mandatory public (PAYG) pension plans, which aim at ensuring a minimum standard of living for all pensioners. This is either done through a universal or basic flat rate pension, a minimum pension (in earnings-related PAYG schemes), or provisions in the social security system available to all citizens. The first pillar contains a strong redistributive element.

- $2^{\text {nd }}$ Pillar: Occupational schemes. This covers employment-related pension plans: either earnings-related PAYG DB plans (public or private), or occupational DC schemes. Schemes may vary in their degree of redistribution, from very limited redistribution in private DC occupational schemes to a larger degree in PAYG DB public schemes, depending on the exact design.

- $3^{\text {rd }}$ Pillar: Individual plans. This covers personal savings plans consisting of voluntary contributions by individuals. They are often privately managed, but can be part of voluntary extra contributions to occupational schemes and managed in the same way. The third pillar makes possible some individualization of the replacement rate. It can also serve as a (favorable tax treated)

11. This system has been followed in Germany, Belgium, Sweden, France and the southern European countries, but also originally in most of the eastern European Member States (with much lower benefit levels).

12. It is important that pension schemes "interact" across pillars. The traditional earnings-related PAYG DB scheme in place in a number of countries has its main part in Pillar II, where it serves to maintain an adequate replacement rate. However, if the earnings-related pension income accrued via the labour market falls short of the minimum pension as defined in Pillar I, the person receives the minimum pension together with any targeted or means-tested benefits. 
means for groups outside the formal labor market to save for retirement. This pillar is rather vaguely defined, since it is not part of provisions on pensions schemes, but rather contracted on a private basis between the individual and the financial institution, with the state intervening financially or on a regulatory basis only in the case of matching or tax incentives.

\section{First Pillar, redistributive pensions}

Pension schemes in Pillar I are, as a general rule, publicly managed PAYG systems mostly based on the DB principle. This type of scheme was the first pension to be introduced in industrialized countries and it has traditionally helped to alleviate income-related risks and decreased poverty levels among the elderly. In most countries, the first pillar serves to set a floor under the income one can expect at retirement age, independent of one's previous labor market attachment. The first pillar is, in principle, the only pillar which can guarantee an adequate pension for all population groups by making sure that the minimum or basic pension, together with additional means-tested pension income, keeps retired people out of poverty.

Since under the pay-as-you-go system, contributions received and pensions paid out must be equal in each period, the underlying link between the employment and/or demographic trend and the level of pension benefits can best be expressed in a simple equation:

Number of contributors * average income ${ }^{*}$ contribution rate

$=$ Number of pensioners * average level of pension

The fewer people contributing, the more contribution rates will have to be raised in order to finance a given pension level. On the other hand, if contribution rates remain constant, then the pensions have to be reduced. Any differences would have to be covered by the government from the current budget.

\section{Ch. 1 - Fig. 19: Contributors over the whole population in France}

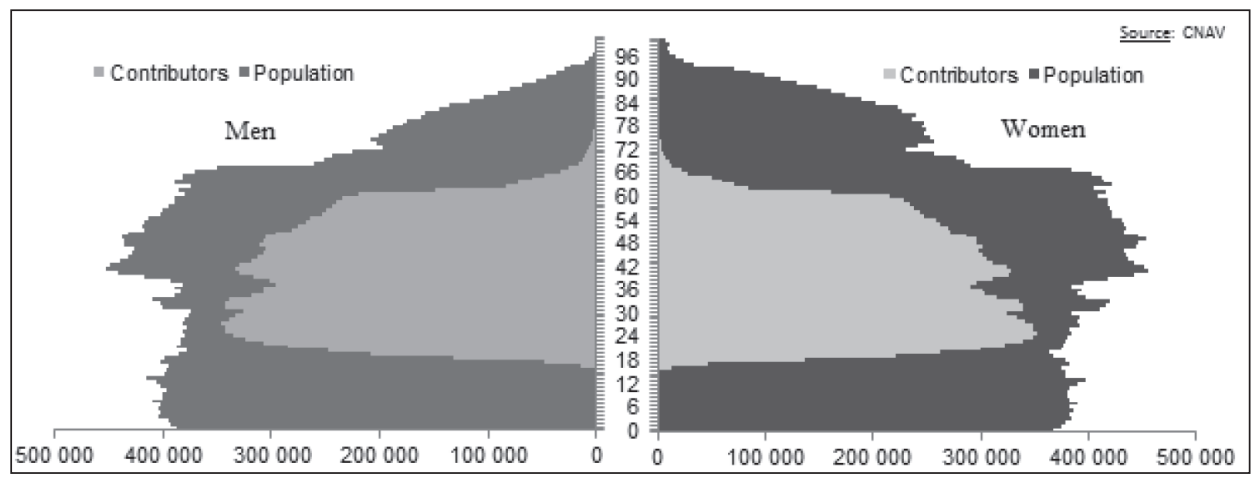

Redistributive schemes in the public Pillar I may differ in their detailed goals and therefore have different formulas determining the value of contributions and 
of benefits in order to fulfil the redistributive and poverty-prevention roles. Three types of redistributive schemes are identified by the OECD ${ }^{13}$ : basic, minimum, and targeted.

- Basic: In basic pension schemes, the benefit is either flat rate, that is, the same amount is paid to every retiree, or the amount is determined by the number of working years (not by past earnings or not linked to labor market participation). Additional income from other sources does not change entitlement to the basic pension. Basic pension schemes are common in the high-income OECD countries and in Eastern Europe and Central Asia.

- Minimum: These schemes are the most common way of approaching the distribution of benefits under the first pillar, but are often combined with targeted help. Minimum pensions ensure a floor under the pension income. Similarly to targeted plans, they also aim to prevent pensions from falling below a certain level. However the institutional set-up and the eligibility conditions are different. Minimum pensions are defined as schemes that are governed by the rules of the second-tier, earnings-related pension provision ${ }^{14}$. Usually, retirees must have paid contributions for a minimum number of years in order to receive benefits.

- Means-tested/targeted:The targeted redistribution scheme refers to conditional provisions dependent on the needs of specific individuals. They depend on current means rather than contributory history. Targeted plans pay higher benefits to poorer pensioners and reduced benefits to better-off retirees. Virtually all of the OECD countries ${ }^{15}$ have some targeted pension scheme or social assistance program.

Different provisions may apply to different cases and they are therefore not exclusive. The three types can co-exist in Pillar I. For example, a country may have a basic provision available for all, and a targeted supplement that is subject to means testing. In addition, there may be a minimum pension that guarantees a minimum income as a pensioner. The minimum can either be higher or lower than the basic provision, if other criteria have to be fulfilled in order to receive basic pension rights, such as a residence requirement.

Most changes undertaken since 2010 in the statutory provisions related to the public Pillar I have concerned the increase or equalization of the age of retirement,

13. OECD (2013), Pensions at a glance 2013: OECD and G20 Indicators, Paris: OECD Publishing.

14. The minimum pension will often be linked to the second pillar: if the labor market attachment has been so weak that the minimum pension has not been reached by the usually earnings related system of Pillar II, the minimum pension will be activated.

15. The targeting takes three different forms. First, benefits may be pension income tested (where the value depends only on the level of pension income a retiree receives), broader income tested (reduced payments if, for example, a retiree has income from savings), or broader means tested (reducing the pension to take account of both income and assets). Some countries do not have specific, targeted programs for older people, but poor older people are entitled to the same general social-assistance benefits available to the whole population. 
or even the removal of the default retirement age altogether. This most common modification of the parameters of the pension schemes does not necessarily alter the characteristics of the pension scheme, although it may have redistributive repercussions. Its main effects are rather increasing employment in certain age brackets and reducing the number of pensioners, most importantly in the long run, as transitional generations sometimes have specific conditions for their retirement.

There are a number of ways governments can contain the costs of the first pillar depending on how generous the minimum or basic pension incomes are from the outset. One ${ }^{16}$ is to adjust these two components for inflation rather than wage growth (the indexation method). The real value of the pension will remain unchanged during retirement, but retirees will be relatively poorer than the working population. Of course, indexation can be done at a level below inflation if a lower real level is deemed adequate. Changing the indexation method is one way to slowly phase in lower benefits in real terms.

\section{Ch. 1 - Fig. 20: Personal income and inflation}

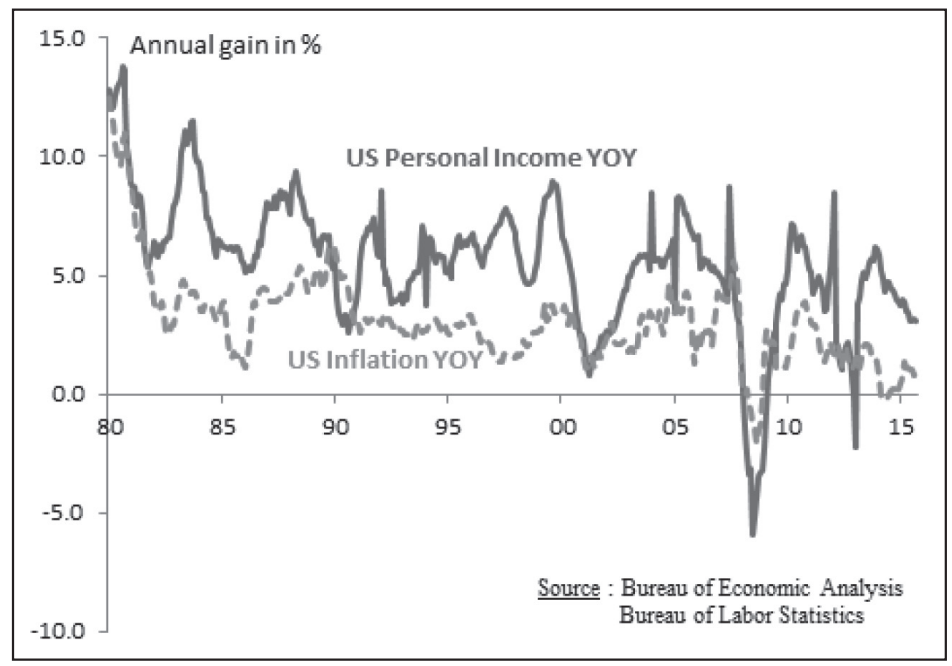

By design, in the first-pillar component of pension systems there is little if any association between contributions (whether through the general tax system or dedicated social security contributions) and benefits received at retirement. For this reason, Pillar I can potentially introduce distortions to the labor market because part of the social security contributions or general taxes does not benefit

16. Another mechanism is to taper the means testing at a faster pace. This means that additional means-tested benefits are only available to the poorest retirees and taper off faster with additional pension income. However, this may have behavioural repercussions in the labour market and on the incentives to build private savings close to retirement age. This is because the taper rate of meanstested benefits acts as an implicit tax on any other pension savings. Thus, a sharper reduction in additional means-tested retirement income may discourage workers from taking up employment close to retirement or from saving in any voluntary third-pillar pension products available. For the same reasons, some workers may also prefer informal employment close to retirement age. 
the individual, but is appropriated to finance a minimum or basic pension and means-tested benefits. However, the distortionary effect of Pillar I is likely to be of second order importance relative to other labor market distortions. Pillar I will have little influence on people's labor supply choice when they are young and their pensions are decades away, but it could influence older workers with very little previous labor market attachment.

Increasing the age at which benefits can first be drawn from Pillar I has been the focus of many recent pension and retirement reforms. This has an immediate and substantial effect on the costs of this part of the pension system. The total effect on public finances may be much less if employment is not available and most people have to be placed on other public support programs. A design that incentivizes people to work longer than the statutory retirement age, compensating them by raising their pension actuarially when they retire, is another way to reduce the cost of Pillar I.

The objective of the first pillar is to provide retirees with a secure minimum income stream avoiding old-age poverty. In the case of systems with universal minimum pensions (i.e. Denmark and the Netherlands), the first pillar adds to the combined replacement rate, but for many income groups it will not in itself provide for a large replacement rate and it therefore contributes only in a limited way towards spreading consumption over the life cycle. However, this does not mean that the first pillar necessarily plays a secondary role in providing for an adequate replacement rate.

The PAYG nature of Pillar I allows for sharing of longevity risk across generations or cohorts, so-called intergenerational risk sharing. Because most increases to life expectancy now take place at old age, this is an important feature. In case of unexpected increases in life expectancy at the retirement age, people will on average spend longer in retirement than expected ${ }^{17}$. This increases the costs of Pillar I pensions. With an unchanged system, the full burden of financing the extra cost will fall on younger generations, either the current working age population via increased social security contributions or taxes, or future generations via the inheritance of a larger public debt. However, risk can be shared by some combination of lower benefits and increased contribution.

Importantly, the notion of intergenerational longevity risk sharing applies only to unexpected changes to the development in longevity. If a Pillar I pension component is perceived as being too generous from the outset, there is no need to invoke the argument of intergenerational risk sharing when reforming it. The PAYG nature of Pillar I means that financial, behavioral and regulatory risks are not present to any large extent.

17. It is worth stressing that the same mechanism would work in the opposite direction in the case of longevity not increasing as expected. The financial cost of the Pillar I pension will then be lower than forecasted, meaning a smaller burden on younger generations in an unchanged system. 
Redistributive components of pension systems are designed to ensure that pensioners achieve some absolute minimum standard of living. Nearly all countries have safety nets that aim to prevent poverty among older people. These schemes, called first-tier ${ }^{18}$, redistributive schemes here, can be of four different types: basic pension schemes, separate targeted retirement-income programs, minimum pensions within earnings-related plans, and social assistance. All of these are provided by the public sector and are mandatory ${ }^{19}$.

\section{Ch. 1 - Fig. 21: Level of benefits as a percentage of average earnings}

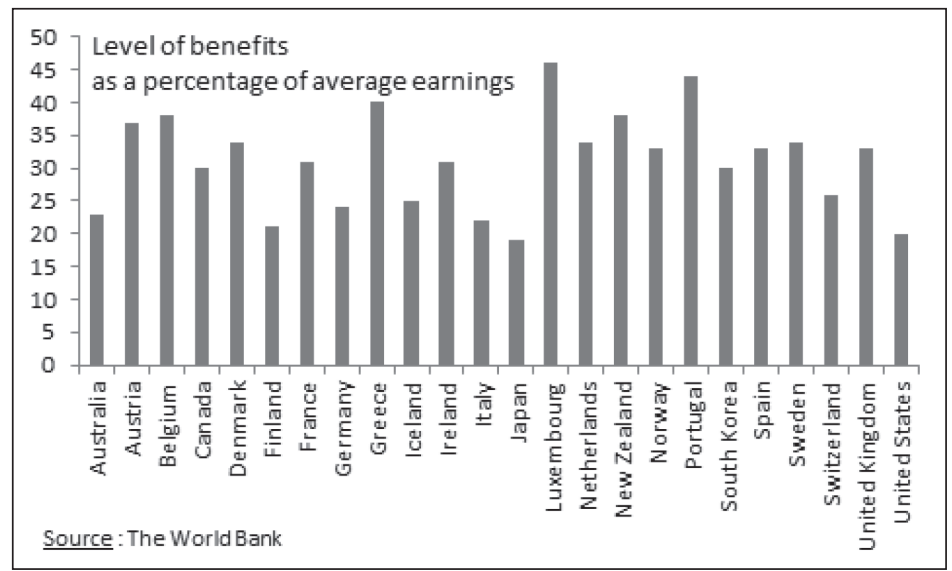

\section{Second Pillar, mandatory insurance}

The second mandatory tier in this typology of pension schemes plays an insurance role. Insurance components are designed to achieve a target standard of living for retirement that is based on the standard of preretirement years. It aims to ensure that retired people have an adequate replacement rate (retirement income relative to earnings before retirement) and not just a poverty-preventing absolute standard of living.

Adequacy is composed of two main elements: poverty reduction and wage replacement. Pillar II is meant to ensure an adequate income replacement rate. A large part of the public pension systems (PAYG) is earnings-related in a sense that the wage should be to some extent commensurate to earnings during a lifetime, therefore taking into account both the wage level and the period of contributions. The formula determining the pension is devised from life-time earnings based on the last earnings or on average earnings during a certain period.

18. Whitehouse, E. - Pension Panorama. Retirement-Income Systems in 53 Countries, The International Bank for Reconstruction and Development / The World Bank, 2007.

19. For the graph, in the cases of minimum pensions and basic pension schemes, the benefit entitlement is shown for workers who enter the workforce at age 20 and work without interruption until they reach the standard pension eligibility age. 
There are three ways of formulating the relation of public pensions to earnings: points systems, notional account systems and defined credits systems:

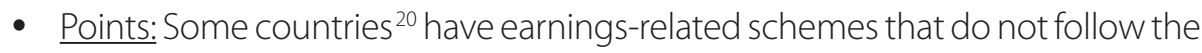
traditional DB model. Workers earn pension points based on their individual earnings for each year of contribution. At retirement, the sum of pension points is multiplied by a pension-point value to convert them into a regular pension payment (see Appendix 1).

- Notional Accounts: These systems ${ }^{21}$ are schemes that record each worker's contributions in an individual account and apply a rate of return to the accounts. The individual accounts are notional: contributions create rights of the contributor and a quantitatively determined liability of the managing institution. The accounts are notional in that both the incoming contributions and the interest charged to them exist only on the books of the managing institution. At retirement, the accumulated notional capital in each account is converted into a stream of pension payments using a formula based on life expectancy at the time of retirement.

- Defined Credits: Privately managed schemes in the second pillar consist of DB and DC pension schemes. They also ensure a link between career-long earnings and the pension benefit. However, in contrast to the public earnings-related schemes in place, private schemes are most often not mandatory. The extent to which this affects pension coverage at retirement depends on how the systems are designed (whether periods of unemployment count towards benefit levels in public schemes). Making defined contribution occupational schemes mandatory or ensuring that incentives are set so that a larger part of the population tends to use them is, to a large extent, a direct way of enhancing the replacement rate of the first and second pillars. One of the main differentiating features of these two systems is the risk of investment and adequacy.

Under DB, the managing institution, usually the state, alternatively a pension fund, bears the investment risk and the (related) risk of providing an adequate pension income. Under DC, there is no guarantee of a minimum real or even nominal income upon retirement, and therefore the risk is entirely borne by the contributor.

- In DB schemes, the amount a pensioner receives depends on the number of years of contributions and on some measure of individual earnings throughout the working life. DB schemes are the only kind of insurance pension found in the Middle East and North Africa. More than half of the high-income OECD countries have public DB programs. Pension plans with DB are determined by formulas taking into account number of years of contributions and the level of earnings for some part of the working career. Benefits do not necessarily

20. In Europe, there are six points systems: the French occupational plans and the Croatian, Estonian, German, Norwegian, and Slovak public pension schemes.

21. Four countries in Europe also have notional-accounts schemes: Italy, Latvia, Poland, and Sweden. 
have a direct link with the (notional) amount contributed. Depending on the parameters of the DB system, contributions to the system throughout active life are generally used only as a condition for benefits, with an element of income adequacy ensuring some degree of differentiation for higher earners. The redistributive character nonetheless implies that higher earners will have lower replacement rates overall than lower earners. The DB system can be translated into a points system under which the final benefits are calculated based on points awarded in proportion to earnings and years of contribution.

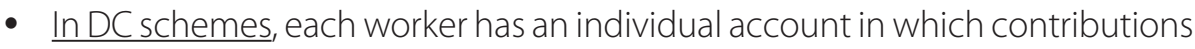
are saved and invested, and the accumulated capital is usually converted into a pension-income stream at retirement; lump-sum withdrawals are rarely permitted. DC systems determine benefits in proportion to the amount contributed rather than to labour participation. Contributions are registered to an individual account which is paid out upon retirement in one form or another. The capital has to be used to buy an annuity (a guaranteed pension payment until death), which meets certain conditions (such as indexation of benefits and provision of survivors' benefits).

Beyond this basic classification, national pension systems also vary in their definition of the accrual rate, which is the rate at which potential benefits rise for each year of contribution. In some countries this accrual rate is strictly linear, in others it changes with earnings or with age. Most countries with earnings-related pension systems apply a progressive formula under the second pillar for replacement rates. This gives low-income groups a higher replacement rate than high-income groups. Some countries offer various ways for their workers to withdraw their pension benefits. Typically, these include life annuities (an insurance company guarantees the payment) or phased withdrawals (a defined portion of the account balance may be taken out each year). In the first case, the risk of longevity is borne by the insurer, which makes the payment as long as the individual survives. In the second case, the individual bears the longevity risk since a long life means that the accumulated balance will be very small at advanced ages.

Risk bearing relates to the bearing of costs in different situations where the outcome in the future is uncertain, for example, with respect to longevity. In some situations, the costs may be borne by employers. Some risks going forward may be initially borne by employers but later shifted to workers. For example, an unexpected decrease in mortality could initially be borne by the employer in a DB plan but later become a cost borne by future workers, when the outcome of improved longevity is built into the expected future costs of the plan. This issue as to the ultimate bearing of costs is not pursued here, where the focus is on the bearing of risks (and costs) in the short run. Another topic that is touched on, but is not explored in depth, is the sharing of risks across generations of workers.

- Investment risk is the risk inherent in financial markets that investments may not perform as expected. Traditional DB plan sponsors generally bear all the financial market risk associated with the plan because the benefits promised 
to participants are not linked to the financial performance of the underlying pension assets. However, the indexation of benefits in payment may be tied informally to the investment performance of the plan's assets, shifting some risk to retirees.

- Longevity risk is the risk that participants will live longer than expected. This risk is pooled and borne by the plan sponsor in DB plans because those plans generally provide annuitized benefits.

- Interest rate risk is the risk resulting from the unpredictable cost of annuities due to swings in interest rates. Annuities provide an element of insurance because retirees are guaranteed benefits as long as they live. If an account balance is converted to an annuity at a higher interest rate, the resulting annuity will be larger. Interest rate risk typically does not arise for participants in traditional DB plans that do not offer lump sum benefits because those plans provide benefits based on a formula, and the benefits they provide are not affected by changes in interest rates at retirement. It does occur, however, for defined benefit plan participants who take lump sum distributions. Interest rate risk does affect employers by affecting the value of pension liabilities in DB plans and by affecting the value of bonds they hold. It affects employers and employees by affecting the value of lump sum benefits.

- Inflation rate risk for participants is the risk that inflation will reduce the real value of benefits in payment or that it will reduce the real value of accrued benefits for participants in DB plans. In a DB plan, inflation can reduce the real value of accrued benefits if it reduces the real value of the earnings base used to calculate those benefits. This effect can happen in a career average DB plan when the wages used to calculate the career average are not fully revalued for inflation. In a DB or DC plan that provides an annuity, generally pension annuities are not fully indexed for inflation, and often no indexing is provided.

Ch. 1 - Fig. 22: Risk distribution for both DB and DC schemes

\begin{tabular}{|lll|}
\hline Risk Distribution & in a DB Pension Plan & in a DC Pension Plan \\
\hline Type of Risk & Who Assumes it? & Who Assumes it? \\
Investment & Employer & Employee \\
Inflation & Employee / Employer & Employee \\
Longevity & Employer & Employee \\
Market timing (temporal) & Employer & Employee \\
Accrual (portability) & Employee & DC plans are portable \\
Vesting & Employee & Employee \\
Employer insolvency & Employee / taxpayers & DC plans always fully funded \\
Salary replacement risk & Employer & Employee \\
& & Employer \\
\hline
\end{tabular}




\section{Third Pillar, voluntary contributions}

Third-pillar pension schemes cover all pension plans where contributions are voluntary, funded and private. As mentioned above, for the purpose of this book, we consider only completely voluntary pension savings as Pillar III. The exact design of third-pillar schemes can vary in many ways, but they are primarily of the DC type due to their private character where the risk is mostly borne by the saver depending on the specific design. Individual third-pillar pension products can be very close in design to occupational schemes in Pillar II. In fact, in some countries' (e.g. Denmark) employees can add voluntary contributions to their occupational scheme and these contributions are then treated on the same terms as contractual contributions ${ }^{22}$.

The decision on saving in a voluntary pension fund is completely individual, and the dynamics and the amount of saving completely depend on the possibilities of each member personally. Because of the voluntary nature of third-pillar pension products, they often carry with them special tax treatment, employee matching contributions, or both. This is supplemented by limits on when and how the assets can be liquidated and paid out so that the character of a pension saving is ensured. In cases where pension tax allowances or other subsidies are scrapped, the pension saving product de facto becomes an ordinary savings product and its value should not be part of the replacement rate, although it could be used as a source of pension income. Since it is the main subject of other chapters, we will not develop the stake of this Pillar at this stage.

\section{Evolution of the retirement systems}

Some financial service providers try to evaluate where the retirement system is the most efficient:

- For example, "The Global Retirement Index" is a multi-dimensional index developed by Natixis Global Asset Management and CoreData Research to examine the factors that drive retirement security and to provide a comparison tool for best practices in retirement policy.

- Mercer annually, together with the Australian Centre for Financial Studies, conducts research into the quality and efficiency of pensions systems globally. The study, titled "Melbourne Mercer Global Pension Index", measures 25 retirement income systems, which cover close to $60 \%$ of the world's population, against more than 40 indicators under the sub-indices of adequacy, sustainability and integrity.

There is, of course, no one-size-fits-all solution to this growing problem. The optimal pension system for any country must take into account domestic factors

22. Mandatory pension funds operate within the mandatory pension insurance on the basis of the individual capitalized savings (Pillar II) while voluntary pension funds operate within the pension system as the voluntary pension insurance on the basis of the individual capitalized savings (Pillar III). 
such as economic, social, cultural and political traditions. However, the policies and practices adopted in some regions that rate highly could hold valuable lessons for other nations that are trying to shore up their systems. Many countries have demonstrated a commitment to innovation and have emphasized simplicity in their retirement scheme's overall design and structure. Many also have proactive governments willing to come together to take bold, sometimes unpopular, policy stances in their ongoing efforts to stabilize retirement security for their citizens.

The DB schemes offer their members a pension benefit guaranteed by a provider (sponsor). This target is expressed in terms of a replacement rate or an amount of lifetime income to be obtained at retirement. It should, however, be recognized that, even in DB schemes, there are vagaries faced by members, as factors such as their future employment status and salary profile are not known with certainty. As such, they still bear substantial uncertainty in the accumulation phase, although they do have relative clarity as to the amount they will get in the decumulation phase (cash-out phase) for a given amount of contributions. Schemes with guarantees from providers or insurers protect pension savings from risks present during the accumulation phase whereas each member bears decumulation risks (they need to buy an annuity or other retirement product).

On the other hand, members of DC pension funds are unable to accurately determine the value of their future pension benefit in advance. It is so because the final value of their pension is uncertain and depends on numerous variables and also decisions that the savers need to take. They are exposed to various risks and are faced with decisions that need to be taken during the saving and, increasingly, decumulation phases. Individuals find it difficult to comprehend information about the on-going performance of their funds. Very often, accumulation and decumulation phases are fragmented because there are separate institutions responsible for pension management in each of these phases. Finally, pure DC schemes do not have targets, at least defined as ones relating to final retirement income, and do not offer risk-sharing during accumulation and decumulation phases. The design of these schemes is more focused on the inputs (amount and period of contributions) which, even where optimized can lead to large variances in members' pension outcomes.

Access is the focus of retirement policy. Now as more of the liabilities and responsibilities of funding retirement are shifting to the individual, policy makers are wise to ensure that workers are actually set up to succeed. The most effective solution to providing greater access is a shared responsibility between government, employers and ultimately individuals.

These problems in DC pension plans coupled with the diminishing role of DB pension arrangements call for consideration of a new paradigm in funded pensions. In several countries there are currently discussions about introducing some long-run retirement target to the DC private pension systems and/or combining desirable features of DB and DC schemes. Various observers have called for creating a more coherent and long-term investment-oriented pension system that would align 
the typically short-term interests of asset managers with the long-term interests of the pension fund members, suggesting that a key role of the regulator or other responsible parties should be to design the system with target annuitisation funds as default options during the accumulation stage.

\section{Towards new plans}

Increasing longevity, the aging of the population, the negative equity returns of the recent financial crisis and prolonged low interest rates have put negative pressure also on DB schemes and undermine the viability of the guarantees offered by employer sponsors. That is why new practical approaches to pension systems to combine the best elements of DB and DC systems are being debated. In establishing risk bearing mechanisms for pension plans, a fundamental question is whether any of the risk will be borne by current retirees. Retirees are often considered to be a vulnerable group. They generally are not able to offset benefit reductions by returning to work.

\section{Hybrid plans}

Hybrid plans combine DB and DC plan features. While a change from a pure DB plan shifts a portion of the risks (and potential rewards) to employees, the hybrid approach typically provides a tax-advantaged means for employees to contribute towards their retirement and to invest in diversified funds. In addition, when used in the public sector, the hybrid approach typically allows employees to convert their DC accounts to an annuity, which adds to the employees' lifetime benefits. In the public sector, hybrid plans are often designed around an approach that uses separate, but coordinated, DB and DC plans ${ }^{23}$.

\section{Cash balance}

Another type of hybrid design used by public sector plans is the "cash balance" approach, which is popular in the private-sector. Under this design, individual accounts are established for employees and credited with a set percentage of the employee's pay (e.g., 6\%) plus interest at a rate established by the plan. The amounts accumulate over time and, at retirement, are payable either in a lump sum or an equivalent annuity, at the election of the employee. In the private sector, these plans are typically funded entirely by the employer. In the public sector, the plans are often funded through both employee and employee contributions.

\footnotetext{
23. The DB plan is typically funded by the employer and provides benefits based on a low multiplier (e.g., $1.0 \%$ or $1.25 \%$ ) applied to final average salary times years of service. Vesting, eligibility for retirement, and distribution options typically mirror those of the traditional DB plan. The DC plan is financed through tax-deferred employee contributions, often set at minimum mandatory level (e.g., $6 \%)$, although additional voluntary employee contributions are often allowed. Employees are able to choose from a variety of investment options. Upon retirement, the DC account balance can be taken as a lump sum or rolled over into an IRA (Individual Retirement Arrangements) or similar plan. In many cases, but not always, the DC account can also be converted to an annuity.
} 
Unlike a traditional DB pension plan or a traditional DC plan, but similar to a nonfinancial DC plan, a cash balance plan provides participants with hypothetical or notional individual accounts. In a cash balance plan, each participant's account is periodically credited with a dollar amount by the sponsoring employer, usually based on a percentage of the participant's salary. They are career average plans in that the contributions allocated to the participant's hypothetical account are based on the participant's pay each year. Participants accrue benefits in a pattern similar to the accrual in a DC plan, with the exception that accrued benefits cannot fall, as can happen in a DC plan during a financial market downturn. Like DC plans, the early years are more heavily weighted than later years. This weighting pattern particularly affects participants whose earnings rise rapidly over their career, providing them a relatively low replacement rate compared to final earnings. Because they have that accrual pattern, the benefits they provide are less closely linked to final salary than in a final average pay plan, and thus the participant faces greater risk as to the replacement rate they will provide.

In a cash balance plan, the employer bears the investment risk of the underlying assets in which the plan is invested, but the participant may bear some investment risk due to fluctuations in the rate of return on the asset underlying the interest credit rate. Participants bear interest rate risk if they choose to convert their account balances to annuities. They bear longevity risk if they do not convert to annuities, which is the usual practice.

Although a cash balance plan portrays benefits to participants in the form of an individual account balance, the cash balance account does not depend on the performance of plan assets. Contributions and investment earnings are not actually allocated to individual accounts; instead, contributions are made to a common trust fund for all participants, and benefits are paid directly from the fund. These plans must provide an annuity option, but typically also provide a lump sum option, which is the most common form of payment.

\section{Defined Ambition}

If introduced, new pension paradigms with income-related targets, whether soft or hard, are likely to bring about significant regulatory changes in various jurisdictions. One such example is the concept of Defined Ambition (DA) schemes being analyzed in the Netherlands and until very recently deliberated in the UK. The Dutch DA schemes, as well as Icelandic schemes, can be defined as a type of plan that targets a stated income-related benefit but which retains the flexibility to lower that target after financial or longevity shocks. Consequently, the target benefits are no longer guaranteed. Notwithstanding, such pensions may be more stable as shocks could be absorbed in small steps. Also, the investment strategy in the DA framework enables to switch from the currently applied inflation protection and short-term nominal asset-liability matching to the long-term indexation of benefits. 
Risk management aims to protect pension members against pension risks such as market risk (adverse price movements), labour market risk (unemployment, health problems or life events that may result in temporal or permanent loss of income from work), longevity risk (lifespan on retirement being longer than expected), interest rate risk, inflation risk, credit risk, etc. In particular, one of the substantial pension risks faced in many DC pension systems relates to the uncertainty about future levels of interest rates that determine annuity prices at the moment of converting accumulated pension savings into a stream of income. Lower interest rates result in lower value of the retirement income stream.

Defined ambition (DA) schemes assume a target expressed as in the DB, albeit the benefit that is aimed for depends ultimately on the funding. Members bear decumulation risks unless annuities are directly supplied by a fund. Investment risk may be shared between members via smoothing returns over time. Depending on the solution used, funds may provide annuities or participants may assume the decumulation risks when buying annuity or other retirement products.

\section{Evolution of both retirement systems and occupational savings}

Efforts to reform retirement systems and enhance or expand workplace or occupational savings plans take different forms globally ${ }^{24}$.

- In seeking to address the demographic concerns facing many European pension systems, Spain has announced measures that will adjust pension parameters every five years based on changing life expectancies. European Commission is expected to launch a legislative proposal on a framework for a Pan-European Personal Pension product (PEPP) ${ }^{25}$. The current fragmentation of national markets in the personal pension sphere means there is less choice and competition than it should. A well-regulated, EU-labelled PEPP would ultimately give people access to low-cost personal pensions and give them the chance to get better returns for their savings. PEPP should be a highly standardised product that can be sold across Member States with an EU product passport. This will generate economies of scale and reduce costs. In particular, investment rules and disclosure requirements should be standardised at EU level. The PEPP framework should give Member States the freedom to introduce country specific rules in a limited number of areas

24. Stańko, D - The concept of Target Retirement Income: supervisory challenges, IOPS Working Papers on Effective Pensions Supervision, No.25, December 2015.

25. The European Fund and Asset Management Association (EFAMA) has been supportive of this project since its inception. EFAMA's briefing shows that households held $€ 7.6$ Trillion in bank accounts at end 2016. This figure represents $41 \%$ of households' financial wealth. This is clearly a huge amount of savings held in short-term, liquid assets, with very limited return potential. At a time when the average replacement rate from public pensions in EU28 is expected to fall to 36\% by 2060, EU citizens should be encouraged to start saving more and earlier, and to re-allocate part of their savings towards more market-based instruments. 
which are central to the organisation of their pension systems, such as the beneficial tax treatment granted to pension products, the determination of the retirement age and the features of eligible pay-out options ${ }^{26}$.

- The Superannuation model implemented in Australia requires employers to contribute a minimum of $9.5 \%$ to employee accounts, while encouraging workers to make additional contributions. The program does not replace basic, minimum government benefits but instead reduces reliance on the public pension system.

- Many OECD countries around the world are partly prefunding their otherwise pay-as-you-go financed social security systems by establishing or further developing existing public pension reserve funds (see Appendix 2).

- Japan is broadening access to the national pension system by reducing the qualifying period from 25 years to 10 beginning in 2017. In addition, a nominal freeze on pension benefits has been abolished and replaced with a new macroeconomic indexation which looks to wages and prices to determine benefit increases.

- To further extend the effectiveness of workplace solutions the U.K. introduced in 2012, standards were set that automatically enroll new employees in their employer's defined contribution scheme as a means of ensuring that individuals are started on the path to retirement savings from the outset.

\section{USA}

In the U.S. ${ }^{27}$, cash balance plans are required to offer annuities as an option, their benefits are expressed as a lump sum, and typically participants withdraw their benefits in the form of a lump sum payment.

Cash balance plans from the perspective of participants have many features of DC plans. Because they provide lump sum benefits, they shift longevity risk to participants. Because they accrue benefits as an account balance, they allow workers to change jobs without suffering portability losses, similar to DC plans. Benefits are accrued over the entire period of participation in the plan, similar to DC plans. Participants also may bear some investment risk, in particular if changes in the crediting rate have some relationship to market rates of return, but the plans provide some protection from investment risk. From the perspective of employers,

26. Finally, the framework should give an adequate degree of flexibility for potential PEPP providers. In this respect, it should be up to the providers to decide whether they want to offer life-cycle investment strategies or strategies with minimum return guarantees as a default option. These considerations as well as the main benefits of the PEPP are summarised in EFAMA's briefing document.

27. The tax code allows individuals to make pre-tax contributions to qualified retirement savings vehicles, which makes participation more attractive. Policy makers have long understood the positive effect that tax incentives have on retirement savings. Across the globe, policy makers are finding that favorable tax treatment is a powerful tool to drive positive behavior in retirement savings. 
however, they have features of DB plans. The cash balance pension formula determines account balances as a function of wages, pay credit rates, and interest credit rates, which can be converted to an annuity.

\section{Canada}

In the Canadian context, a target benefit plan called Shared Risk Pension Plan (SRR) was introduced in New Brunswick in 2012. Employer and employee contributions can vary between $8 \%$ and $10 \%$ of salary depending on the funded status of the plan. The accrued benefits may be subject to a reduction if the funding level falls below a given threshold. The target is expressed as a replacement rate as is done in an "ordinary" DB pension plan. However, benefits are calculated on the basis of career average salary, usually lower than final salary, with possible indexation of employee salaries to wage growth or inflation. The plan of New Brunswick applies an interesting risk-sharing model that clearly spells out how the sponsor would respond in the case of worsening or improving financial situation of a plan. Depending on the quality of the funded ratio, changes can occur in several key parameters of the plan. A deteriorating funded ratio may, for example, result in: an increase of contributions (that can be split between employer and employee); a change of the rule for calculating early benefits to more strict (actuarial) ones; a reduction of "base benefit" accrual rate or a reduction of 'base benefits'. Improvements of the funded ratio can reverse such previous deficit-recovery measures and, if sufficient, can increase the individual benefits.

\section{Sweden}

Nonfinancial DC (NDC) plans, also called Notional DC plans, establish an individual account for each participant. The participant's contributions are credited to the account, as are notional interest earnings on the account. However, the system is financed on a pay-as-you-go basis, and thus differs from a cash balance plan, which also provides notional accounts, but is funded. A collectively managed trust fund is maintained to cover periods when payroll tax payments are temporarily low. The trust fund thus has the role of filling in gaps when contributions are low due to an economic downturn. The trust fund also is designed to help pay for the retirement of the baby boom generation. Without such a trust fund, the retirement of the baby boom generation would result in a large reduction in benefits.

NDC plans are similar to DC plans in that both define benefits for participants in terms of an account balance. In DC plans, however, the participant bears the financial market risk associated with the underlying assets in which the plans are invested. In NDC plans, the crediting rate on participants' account balances is established 
in advance at a fixed rate or is tied to an index ${ }^{28}$, typically related to the growth in wages. NDC plans typically index benefits at retirement for changes in life expectancy at the benefit entitlement age. Life expectancy indexing in NDC plans is a natural outcome of the structure of these plans because they accrue benefits in the form of an individual account balance. The account balance is then converted to an annuity using current life expectancy ${ }^{29}$, just as is done in DC plans.

\section{Denmark}

The purpose of the Danish pension fund is to secure the highest possible real value of pension. The Fund guaranteed pension target is a promise of a guaranteed lifelong nominal income stream at retirement. There is a clear link between the contributions that are paid to the scheme and the pension rights accrued by the individual member. Future pension is gradually built up as a sum of promises acquired year by year during savers' working life. Under the Danish model, pension contributions are annuitised from the start, which means technically that savers purchase specific deferred annuities each year when contributing. The stream of future lifelong income consists in principle of a large number of year specific deferred annuities and is guaranteed with the use of financial instruments (interest rate swaps). The size of the guarantee depends on actuarial assumptions about mortality and the interest rate curve. The funds are invested; if there is any surplus in excess of guaranteed pensions it is used to finance further increase of guarantees.

28. If the growth rate of real per capita wages is constant at 1.6 percent per year, the social security annuity is adjusted solely by changes in the Consumer Price Index (CPI). If the annual growth rate of real per capita wage income falls below 1.6 percent, the cost of living adjustment is less than the increase in the CPI, and if the growth rate of real per capita wage income exceeds 1.6 percent, the adjustment is greater than the CPI. For example, if the annual growth rate in real per capita wages were 1.5 percent, the increase in benefits in payment would be the rate of growth of the CPI minus 0.1 percent. Thus, Swedish pensioners share risk with participants in the fluctuations in the Swedish economy and in the long-term growth of the economy. In an economic recession, such as preceded the passage of the reform legislation, indexed benefits of Swedish pensioners are reduced below the level provided by price indexing.

29. Each year, due to the life expectancy indexing of benefits, the initial benefits received by new beneficiaries are adjusted downward as a new birth cohort reaches the eligibility age of 61 . Life expectancy indexing of benefits is done by an adjustment that reflects improvements in life expectancy at age 65. No further adjustments to retirees' benefits are made for improvements in mortality after age 65. Mortality experience is averaged over the previous five years to avoid year-toyear fluctuations that do not reflect longer- term trends. The Swedish system uses period mortality tables, which are mortality tables based on the experience of the cross section of older persons, not projecting future mortality improvements. The life expectancy adjustment in Sweden does not affect retirees once benefit payment has started. 


\section{Netherlands}

The Dutch collective DB pension schemes members build up their future pension rights equivalent to a fixed percentage of the salary. The contribution rate is the same, irrespective of individual characteristics (such as age, gender, health or income). In a career average Dutch DB plan, the indexation of accrued benefits and pensions in force aims to keep pace with inflation. Nevertheless, such annual indexation is contingent on the plan funding status. In effect, conditional indexation shifts some of the investment risk as well of the longevity and interest rate risks from employer to participants. In Dutch collective DC pension schemes, benefits depend on the employee's average career salary and number of years in the plan. Longevity risk can be shared between participants and employers, whereas investment risk is borne by participants.

\section{Switzerland}

In Switzerland, the target for occupational pension funds (hybrid type, with annuitisation carried out within the funds) is set up in conjunction with the state first pillar although the joined perspective is not explicitly expressed in legislation. The Swiss Constitution stipulates that the second pillar combined with the first pillar should enable the insured persons to maintain their previous lifestyle in an "appropriate" manner. The general consensus assumes that the final replacement rate from both pillars should be at least $60 \%$ of the gross final salary. This is a targeted, not guaranteed, outcome and is set up under the condition of obtaining a full pension. The members and retirees of Swiss occupational pension schemes share investment risk because the actual values of interest on savings can be changed depending on the financial situation of the fund. The system is quite flexible and is evaluated every 10 years with parameters being changed accordingly. However, the system is affected by increasing life expectancy and falling interest rates, with both factors pressing for lower conversion rates. Some pension funds use their own system of target retirement income. The state pension targets pension replacement is 30\% of final salary and contributions to occupational schemes are backed with a minimum interest rate guarantee from the government.

\section{Chile}

The unemployment insurance system in Chile aims to provide monetary benefits to affiliated eligible workers who are unemployed. The system is financed by a combination of employer and employee contributions which are saved in two different funds: a short-term fund operating individual unemployment accounts, and a medium-term fund (Solidarity Unemployment Fund) but with the need to be available at critical times (when benefits claims accumulate, for instance during a financial crisis; recession; periods of increased unemployment, etc.). The state also 
contributes some resources. The distinction from the unemployment scheme is that the retirement target here would not be the profitability itself but the probability that pension fund members will obtain a given replacement rate considering the lifetime of the contributor and the main types of risks (such as investment, human capital, annuitisation and longevity risks) ${ }^{30}$. The Chilean model puts more emphasis on individual savings, creating a savings vehicle and minimum contribution levels of $10 \%$ of earnings to ensure workers accumulate much-needed retirement assets. Similarly, it does not replace the government retirement benefits, but instead shares the pension funding liability with individuals.

\section{Emerging countries}

One cannot talk about future trends in retiree welfare without paying special attention to the world's emerging powers. Not only do these countries account for a rapidly increasing share of GDP, due to above average "catch-up" economic growth, but they will also be home to a huge proportion of the world's retirees.

The BRIC nations (Brazil, Russia, India and China) have been touted as future world powers with their economies growing at more than 3\% a year since 2001. The latest data reveals that BRIC countries account for $28.9 \%$ of the world's GDP. However, there are existing and future headwinds that these giants will need to navigate. According to data from the World Bank, BRIC countries are still seeing their share of global output grow (in purchasing power parity terms), albeit at a slower growth rate.

The provision of old-age insurance, in the way of pensions and healthcare for retirees, is going to be one of the priorities, and therefore one of the pillars, of any new welfare state. This will undoubtedly play a major role in determining the level of welfare of retirees in these countries and ultimately their desirability as retirement destinations. While the retirement issue might not seem a pressing one, as the BRIC nations have young populations relative to their developed country counterparts, this is likely to change rapidly given decreasing fertility rates and higher life expectancy, which will result in a demographic inflection point and rapidly aging populations. In fact, recent data captures the trend that old-age dependency ratios for BRIC countries have drastically increased. Russia has the highest ratio among the four, and China just rose above the world average in 2013. The old-age dependency ratio, defined as the proportion of people aged 65 and over who depend on the working population, has increased in the BRIC nations. The urgency of the situation has led China to repeal its decades-long one child policy and increase it to two children per couple. In reality, this change will take years to take effect.

30. Stochastic simulations can give a set of such possible pension outcomes in terms of replacement rate against the risk expressed as standard deviation of the replacement rate. 


\section{Appendix 1: Pension with points}

We suppose that the retirement system is as follow:

- one worker is active from age $i=0$ to age $i=T$ and retired from $i=T+1$ to $i=T+N$

- $\quad T$ is the length of activity and $N$ the length of retirement

- $W_{t}^{i}$ is the salary at age $i$ and time $t$

- every year, the workers with age acquire some points with contributions $\sigma W^{i}$

- the pension is linked to the aggregation of point, discounted with a rate $\rho$

- so, $Q_{t}^{T+1}$ the total of points that the retired will have for his first pension in $t$

- $\quad p$ being the constant inflation rate

- $\Pi$ the constant productivity gains

- so the salary growth at $\frac{W_{t+1}^{i}-W_{t}^{i}}{W_{t}^{i}}=p . \Pi$

Then we have: $Q_{t}^{T+1}=\sum_{i=1}^{T} \sigma W_{t+i-(T+1)}^{i}(1+\rho)^{T+1-i}$

In $T+1$, the first pension $r_{t}^{T+1}$ is a fraction $\mu$ of the total points cumulated by the worker and continue to growth during retirement with a rate $p+\lambda \Pi: r_{t}^{T+1}=\mu W_{t-1}^{T}(1+p+\lambda \Pi)$

Then the pension $r$ is indexed on prices and a part $\lambda$ of productivity gains: $\frac{r_{t+1}^{i+1}-r_{t}^{i}}{r_{t}^{i}}=p+\lambda \Pi$ And the total retirement $R_{t}$ payed by the system in $t$ is:

$R_{t}=\sum_{j=1}^{N} r_{t}^{T+j}$ with $r_{t}^{T+j}=r_{t-(j-1)}^{T+1} \cdot(1+p+\lambda \Pi)^{j-1}$ and $r_{t-(j-1)}^{T+1}=\mu Q_{t-(j-1)}^{T+1}$ so :

$R_{t}=\sum_{j=1}^{N} \mu Q_{t-(j-1)}^{T+1} \cdot(1+p+\lambda \Pi)^{j-1}$

\section{Appendix 2: Public Pension Reserve Fund}

With the creation of a Public Pension Reserve Fund, the relationship between resources and uses of the retirement system becomes:

- the resources: Contributions $C_{t}+$ Additional complements $A_{t}+$ Fund at beginning $F_{t-1}$

- the uses: Benefits paid $B_{t}+$ Reserve Fund at year end $F_{t}$

With $r_{t}$ the return for the invested assets we have:

$C_{t}+A_{t}+(1+r) \cdot F_{t-1}=B_{t}+F_{t}$ 